\title{
NIST/NIH Vitamin D Metabolites Quality Assurance Program Report of Participant Results: Summer 2013 Comparability Study (Exercise 7)
}

\author{
Mary Bedner \\ Katrice A. Lippa \\ Susan S.-C. Tai
}

This publication is available free of charge from:

http://dx.doi.org/10.6028/NIST.IR.8000

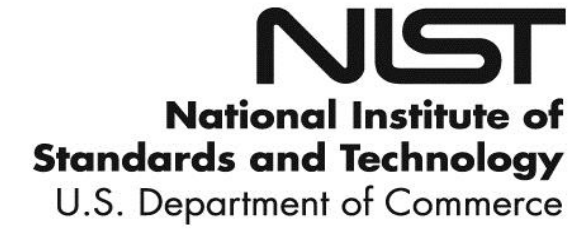




\title{
NIST/NIH Vitamin D Metabolites Quality Assurance Program Report of Participant Results: Summer 2013 Comparability Study (Exercise 7)
}

\author{
Mary Bedner \\ Katrice A. Lippa \\ Susan S.-C. Tai \\ Chemical Sciences Division \\ Material Measurement Laboratory
}

This publication is available free of charge from:

http://dx.doi.org/10.6028/NIST.IR.8000

February 2015

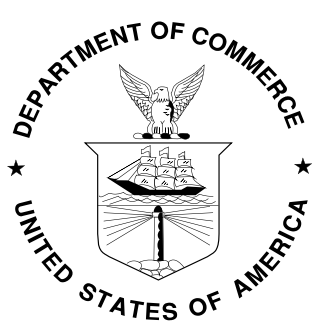

U.S. Department of Commerce

Penny Pritzker, Secretary 


\begin{abstract}
The National Institute of Standards and Technology (NIST) has established a Vitamin D Metabolites Quality Assurance Program (VitDQAP) in collaboration with the National Institutes of Health (NIH) Office of Dietary Supplements. Participants in the seventh exercise of this program, the Summer 2013 Comparability Study, were asked to use the methodology of their choice to measure concentrations of 25-hydroxyvitamin D in pooled human serum control and study materials distributed by NIST. The study materials consisted of SRM 972a Vitamin D Metabolites in Human Serum Level 4 and VitDQAP-II (a material designed for the VitDQAP). SRM 968e Fat-Soluble Vitamins, Carotenoids, and Cholesterol in Human Serum Level 1 was provided as a control material. Participants provided their data to NIST, where it was compiled and evaluated for trueness relative to the NIST value and concordance within the participant community. A report of results was provided to all participants of the study, and laboratories were identified by code numbers known only to them. The results from this seventh study are reported along with a summary of the analytical methods used.
\end{abstract}




\section{OVERVIEW OF THE SUMMER 2013 COMPARABILITY STUDY}

For the Summer 2013 comparability study of the VitDQAP, pooled human serum control and study samples were distributed to participants for evaluation. SRM 968d Fat-Soluble Vitamins, Carotenoids, and Cholesterol in Human Serum Level 1 (SRM 968d L1) was provided as a control material for assay calibration or verification. The blinded study samples consisted of two vials, Vial A and Vial B. Vial A was VitDQAP-II, which contains only endogenous 25hydroxyvitamin D (25(OH)D) levels. Vial B was SRM 972a Vitamin D Metabolites in Human Serum Level 4 (SRM 972a L4), which contains endogenous levels of 25-hydroxyvitamin $\mathrm{D}_{2}$ $\left(25(\mathrm{OH}) \mathrm{D}_{2}\right)$ and 25-hydroxyvitamin $\mathrm{D}_{3}\left(25(\mathrm{OH}) \mathrm{D}_{3}\right)$ but was fortified with 3-epi-25hydroxyvitamin $\mathrm{D}_{3}$ (3-epi-25(OH) $\mathrm{D}_{3}$ ). Participants were asked to provide individual concentration values for $25(\mathrm{OH}) \mathrm{D}_{2}, 25(\mathrm{OH}) \mathrm{D}_{3}$, and 3-epi-25(OH) $\mathrm{D}_{3}$ along with a total concentration of $25(\mathrm{OH}) \mathrm{D}\left(25(\mathrm{OH}) \mathrm{D}_{\text {Total }}=25(\mathrm{OH}) \mathrm{D}_{2}+25(\mathrm{OH}) \mathrm{D}_{3}\right)$ for the control and each study sample.

There were a total of 44 participants and 49 datasets (five participants provided data from two different methods) in the Summer 2013 comparability study. Sixteen of the datasets originated from immunoassay (IA) techniques, including 13 from chemiluminescence immunoassay (CLIA) and three from radioimmunoassay (RIA). Note that none of the participants used enzyme immunoassay (EIA) in this study. Appendix A-1 summarizes the IA methods used by the participants. Thirty-three of the datasets originated from liquid chromatographic (LC) methods; of those, 30 were from $\mathrm{LC}$ with tandem mass spectrometric detection $\left(\mathrm{LC}^{\mathrm{M}} \mathrm{MS} \mathrm{S}^{\mathrm{n}}\right)$, and three were from LC with ultraviolet absorbance detection (LC-UV). A summary of the LC methods used by the participants may be found in Appendices A-2 and A-3.

The raw data received from all participants are summarized in Appendix B. All datasets from the immunoassay methods reported a single value for $25(\mathrm{OH}) \mathrm{D}_{\text {Total }}$ whereas LC participants provided values for $25(\mathrm{OH}) \mathrm{D}_{2}, 25(\mathrm{OH}) \mathrm{D}_{3}$, and 3 -epi-25(OH)D3 as well as $25(\mathrm{OH}) \mathrm{D}_{\text {Total }}$ in VitDQAP-II (Vial A), SRM 972a L4 (Vial B), and SRM 968d L1 (Control).

Appendix B also provides the summarized NIST results for each of the serum materials.

The control material (SRM 968d L1) and the two study samples (SRM 972a L4 and VitDQAPII) all contain low levels of $25(\mathrm{OH}) \mathrm{D}_{2}$, thus $25(\mathrm{OH}) \mathrm{D}_{3}$ represents the predominant metabolite contributing to $25(\mathrm{OH}) \mathrm{D}_{\text {Total }}$. However, the two study materials, VitDQAP-II (Vial A) and SRM 972a L4 (Vial B), both contain measurable amounts of 3-epi-25(OH) $\mathrm{D}_{3}$. 


\section{SUMMER 2013 COMPARABILITY STUDY RESULTS AND DISCUSSION}

\section{5(OH)DTotal in VitDQAP-II (Vial A), SRM 972a L4 (Vial B), and SRM 968d L1 (Control)}

A summary of the individual participant data for $25(\mathrm{OH}) \mathrm{D}_{\text {Total }}$ in VitDQAP-II (Vial A), SRM 972a L4 (Vial B), and SRM 968d L1 (Control) is provided in Table 1.

The community results are summarized at the bottom of Table 1 for all reported methods, the IA methods only, the LC methods only, and the LC-MS methods only. The community results include the total number of quantitative values reported $(\mathrm{N})$, the median value for each analyte, the MADe (the median absolute deviation estimate, a robust estimate of the standard deviation), and the percent coefficient of variation $(\mathrm{CV} \%)$.

Table 1 also presents the NIST results for the three study materials. For SRM 972a L4 (Vial B), the NIST result is the sum of the certified values for $25(\mathrm{OH}) \mathrm{D}_{3}$ and $25(\mathrm{OH}) \mathrm{D}_{2}$ with the corresponding $95 \%$ confidence limits $\left(U_{95}\right)$.

The NIST values for 25(OH)D ${ }_{3}$ in VitDQAP-II $(\mathrm{N}=8)$ and SRM 968d L1 $(\mathrm{N}=5)$ were obtained using an LC-MS/MS reference measurement procedure (RMP) ${ }^{1}$ recognized by the Joint Committee for Traceability in Laboratory Medicine (JCTLM). The NIST value for $25(\mathrm{OH}) \mathrm{D}_{2}$ was also obtained using the RMP for VitDQAP-II $(\mathrm{N}=5)$, but for SRM 968d L1 the value was well below the limit of quantitation and was estimated to be $0.1 \mathrm{ng} / \mathrm{mL}(\mathrm{N}=1)$. The NIST values for $25(\mathrm{OH}) \mathrm{D}_{\text {Total }}$ in VitDQAP-II (Vial A) and SRM 968d L1 (Control) reported in Table 1 are the sum of the individual values for $25(\mathrm{OH}) \mathrm{D}_{3}$ and $25(\mathrm{OH}) \mathrm{D}_{2}$, and the $95 \%$ confidence limit $\left(U_{95}\right)$ incorporates the uncertainties for the two analytes and includes components for measurement variability and measurement uncertainty associated with the density of the materials.

For SRM 968d L1 (Control), the participants were provided the NIST target values within the data reporting sheet so that they could qualify their methods prior to analyzing the study samples.

\footnotetext{
${ }^{1}$ Tai, S. S.-C., Bedner, M. and Phinney, K.W. Anal. Chem. 2010 82, 1942-1948.
} 
Table 1. Summary of participant data for $25(\mathrm{OH}) \mathrm{D}_{\text {Total }}(\mathrm{ng} / \mathrm{mL})$ in VitDQAP-II (Vial A), SRM 972a L4 (Vial B), and SRM 968d L1 (Control).

\begin{tabular}{|c|c|}
\hline Lab & Method \\
\hline 017 & CLIA \\
\hline 030 & RIA \\
\hline 056 & LC-MS/MS \\
\hline 060 & LC-MS/MS \\
\hline 086a & CLIA \\
\hline 110 & LC-UV \\
\hline 116 & LC-MS/MS \\
\hline 119 & LC-MS/MS \\
\hline 128 & LC-MS/MS \\
\hline 139 & LC-UV \\
\hline $183 b$ & CLIA \\
\hline 187 & LC-MS/MS \\
\hline 188 & CLIA \\
\hline 194 & LC-MS/MS \\
\hline 196 & CLIA \\
\hline 197 & LC-MS/MS \\
\hline $198 a$ & LC-MS/MS \\
\hline $198 c$ & CLIA \\
\hline 199 & LC-MS/MS \\
\hline 200 & $\mathrm{RIA}$ \\
\hline 209 & LC-MS/MS \\
\hline $210 a$ & RIA \\
\hline $210 b$ & CLIA \\
\hline 211 & LC-MS/MS \\
\hline $213 a$ & CLIA \\
\hline $214 b$ & CLIA \\
\hline $214 c$ & LC-MS/MS \\
\hline 215 & LC-MS/MS \\
\hline 216 & LC-MS/MS \\
\hline 217 & LC-MS/MS \\
\hline $218 a$ & CLIA \\
\hline $218 b$ & LC-MS/MS \\
\hline 220 & LC-MS/MS \\
\hline $221 a$ & LC-MS/MS \\
\hline 222 & CLIA \\
\hline 225 & LC-MS/MS \\
\hline $228 a$ & LC-MS/MS \\
\hline 231 & LC-UV \\
\hline 241 & LC-MS/MS \\
\hline 242 & LC-MS/MS \\
\hline 244 & LC-MS/MS \\
\hline $247 a$ & CLIA \\
\hline 248 & LC-MS/MS \\
\hline 249 & LC-MS/MS \\
\hline 250 & LC-MS/MS \\
\hline 253 & LC-MS/MS \\
\hline $254 a$ & LC-MS/MS \\
\hline $254 b$ & CLIA \\
\hline 255 & LC-MS/MS \\
\hline$=\frac{\substack{0 \\
0}}{c}$ & $\begin{array}{r}\text { Median } \\
\text { MADe } \\
\text { CV\% }\end{array}$ \\
\hline$\leq \frac{\stackrel{0}{0}}{\stackrel{0}{c}}$ & $\begin{array}{r}\text { Median } \\
\text { MADe } \\
\text { CV\% }\end{array}$ \\
\hline ن & $\begin{array}{r}\text { Median } \\
\text { MADe } \\
\text { CV\% }\end{array}$ \\
\hline 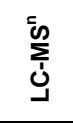 & $\begin{array}{r}\text { Median } \\
\text { MADe } \\
\text { CV\% }\end{array}$ \\
\hline
\end{tabular}

\begin{tabular}{|c|c|c|}
\hline VitDQAP-II & SRM 972a L4 & SRM 968d L1 \\
\hline Vial A & Vial B & Control \\
\hline 36.8 & 27.0 & 13.0 \\
\hline 33.6 & 26.3 & 12.8 \\
\hline 36.4 & 27.5 & 12.3 \\
\hline 39.4 & 30.9 & 12.8 \\
\hline 40.7 & 30.7 & 14.0 \\
\hline 30.1 & 44.7 & 13.2 \\
\hline 36.7 & 24.4 & 16.5 \\
\hline 41.7 & 65.3 & 15.1 \\
\hline 24.8 & 33.5 & 12.3 \\
\hline 44.2 & 64.4 & 14.7 \\
\hline 37.0 & 29.2 & 13.5 \\
\hline 39.6 & 59.7 & 12.5 \\
\hline 47.0 & 35.2 & 13.6 \\
\hline 43.4 & 64.5 & 12.5 \\
\hline 40.9 & 29.6 & 14.6 \\
\hline 33.9 & 46.7 & 12.8 \\
\hline 49.7 & 56.6 & 11.4 \\
\hline 40.8 & 26.6 & 15.4 \\
\hline 41.5 & 71.0 & 12.7 \\
\hline 30.8 & 22.9 & 12.8 \\
\hline 42.4 & 49.7 & 13.0 \\
\hline 38.5 & 34.5 & 8.5 \\
\hline 40.8 & 39.8 & $<3.0$ \\
\hline 42.0 & 58.0 & 15.3 \\
\hline 49.2 & 49.8 & 9.0 \\
\hline 39.6 & 28.8 & 13.1 \\
\hline 36.1 & 53.7 & 12.1 \\
\hline 40.4 & 57.2 & 13.9 \\
\hline 38.2 & 29.3 & 12.6 \\
\hline 37.2 & 54.0 & 12.8 \\
\hline 37.5 & 28.6 & 12.8 \\
\hline 42.3 & 42.7 & 13.1 \\
\hline 39.0 & 59.0 & 13.0 \\
\hline 35.5 & 25.1 & 16.9 \\
\hline 51.6 & 34.8 & 12.4 \\
\hline 44.6 & 65.9 & 11.2 \\
\hline 34.6 & 51.6 & 12.4 \\
\hline 41.3 & 56.4 & $\mathrm{n} / \mathrm{r}$ \\
\hline 43.3 & 68.0 & 14.9 \\
\hline 35.1 & 30.5 & 11.9 \\
\hline 36.5 & 43.1 & 12.5 \\
\hline 50.0 & 34.1 & 13.1 \\
\hline 43.0 & 55.0 & 14.0 \\
\hline 36.4 & 29.1 & 12.4 \\
\hline 44.3 & 67.7 & 13.9 \\
\hline 41.7 & 33.0 & 14.1 \\
\hline 40.5 & 59.5 & 12.9 \\
\hline 37.5 & 29.6 & 12.5 \\
\hline 50.1 & 60.4 & 16.4 \\
\hline 49 & 49 & 47 \\
\hline 40.4 & 42.7 & 12.9 \\
\hline 4.7 & 20.2 & 0.9 \\
\hline 11.7 & 47 & 6.9 \\
\hline 16 & 16 & 15 \\
\hline 40.2 & 29.6 & 13.0 \\
\hline 4.3 & 4.7 & 0.7 \\
\hline 10.7 & 16 & 5.7 \\
\hline 33 & 33 & 32 \\
\hline 40.4 & 54.0 & 12.9 \\
\hline 4.7 & 15.6 & 0.8 \\
\hline 11.7 & 28.8 & 6.3 \\
\hline 30 & 30 & 30 \\
\hline 40.0 & 53.9 & 12.8 \\
\hline 4.9 & 16.2 & 0.7 \\
\hline 12.2 & 30.1 & 5.8 \\
\hline
\end{tabular}

NIST Value

\begin{tabular}{|c|c|c|}
\hline 37.5 & 30.0 & 12.5 \\
1.0 & 1.0 & 0.3 \\
\hline
\end{tabular}


For all participant datasets, the single reported values for $25(\mathrm{OH}) \mathrm{D}_{\text {Total }}$ in VitDQAP-II (Vial A), SRM 972a L4 (Vial B), and SRM 968d L1 (Control) are plotted in Figure 1, Figure 2, and Figure 3, respectively. The results from immunoassay methods are displayed with open dark blue circles ( $\circ$ ), and the results from the LC-based methods are displayed with open light blue circles $(\circ)$. For the LC results in all three figures, the majority of the data points are from LC$\mathrm{MS}^{\mathrm{n}}$ methods. However, the LC-UV results were sorted separately and are plotted at the right end of the LC results as labeled.

From the single reported values for all LC datasets for a given technique (IA or LC), the consensus median and the consensus variability $(2 \times \mathrm{MADe})$ were determined. For both of the major techniques (IA or LC) in each figure, the solid lines (- ${ }_{-}$) and $(-)$represent the consensus median, and the dashed lines (- - - ) and (- - - ) represent the approximate $95 \%$ confidence interval $(2 \times$ MADe). The laboratories with results that fall between the two dashed lines are within the consensus variability area for their technique (IA or LC).

The red lines $(-$ ) in each figure (Figures 1 - 3) represent the NIST value and its associated uncertainty (i.e., value $\pm U_{95}$ ). NIST believes that the "true" value for each material lies within this interval. When these lines are not within the consensus range, then there may be method bias.

Specific results for each of the three study materials are summarized below:

\section{VitDQAP-II (Vial A): Figure 1}

- For the IA results, four reported values are outside of the consensus variability range (three CLIA, one RIA).

- For the LC results, three reported values are outside of the consensus variability range (two LC-MS ${ }^{\mathrm{n}}$, one LC-UV).

- The consensus median values for both the LC and IA results agree well with each other but are slightly higher than the NIST expanded uncertainty range (red lines).

- The NIST expanded uncertainty range (red lines) falls within the consensus variability ranges both for LC and IA results.

SRM 972a L4 (Vial B): Figure 2

- For the IA results, two reported values are outside the consensus variability range (both CLIA).

- For the LC results, the consensus variability range is very large, and there are no outliers.

- The consensus median value for the IA results agrees well with the NIST expanded uncertainty range (red lines).

- The consensus median value for the LC results is considerably higher (80\%) than both the IA median value and the NIST expanded uncertainty range (red lines).

- The NIST expanded uncertainty range (red lines) falls within the consensus variability ranges for both IA and LC results.

SRM 968d L1 (Control): Figure 3

- For the IA results, two reported values are outside of the consensus variability range (both CLIA). 
- For the LC results, eight reported values are outside of the consensus variability range (seven $\mathrm{LC}^{-M S}{ }^{\mathrm{n}}$, one LC-UV).

- The consensus median value for the IA results is comparable to the consensus median value for the LC results; both LC and IA median values are slightly higher than the NIST expanded uncertainty range (red lines).

- The NIST expanded uncertainty range (red lines) falls within the consensus variability range for both LC and IA.

The consensus variability of $\approx 7 \%$ to $12 \%$ (all methods) for SRM 968d L1 (Control) and VitDQAP-II (Vial A) is consistent with participant performance for other materials containing predominantly $25(\mathrm{OH}) \mathrm{D}_{3}$ that were evaluated in previous comparability studies of the VitDQAP.

For SRM 972a L4 (Vial B), the LC results are bimodal, where nine reported results agree well with both the NIST value and the reported IA results, but the majority of the LC results (73\%) are biased high (Figure 2). The bimodal results contribute to the large consensus variability (47\%) for this material when the results for all methods are considered (Table 1). SRM 972a L4 (Vial B) was fortified with 3-epi-25(OH) $\mathrm{D}_{3}$, and the NIST-certified value for this vitamin $\mathrm{D}$ metabolite is $26.4 \mathrm{ng} / \mathrm{mL} \pm 2.1 \mathrm{ng} / \mathrm{mL}$. The biological significance of 3-epi- $25(\mathrm{OH}) \mathrm{D}_{3}$ is uncertain, and this metabolite is not included in the $25(\mathrm{OH}) \mathrm{D}_{\text {Total }}$ concentration. Therefore, LC methods that do not chromatographically separate the 3-epi- $25(\mathrm{OH}) \mathrm{D}_{3}$ yield biased results for $25(\mathrm{OH}) \mathrm{D}_{3}$ and hence $25(\mathrm{OH}) \mathrm{D}_{\text {Total }}$ because the 3 -epi-25(OH) $\mathrm{D}_{3}$ and the $25(\mathrm{OH}) \mathrm{D}_{3}$ are diastereomers that are detected by the same multiple reaction monitoring (MRM) ions in MS/MS and absorbance wavelength in UV. Since the majority of the reported LC methods do not separate the $25(\mathrm{OH}) \mathrm{D}_{3}$ and 3-epi-25(OH)D 3 (Appendix A-2, A-3), the median LC value of 54.0 $\mathrm{ng} / \mathrm{mL}$ for $25(\mathrm{OH}) \mathrm{D}_{\text {Total }}$ in SRM $972 \mathrm{a} \mathrm{L4}$ is biased $80 \%$ higher than the NIST value of 30.0 $\mathrm{ng} / \mathrm{mL} \pm 1.0 \mathrm{ng} / \mathrm{mL}$. The majority of the IA methods, on the other hand, do not have crossreactivity with the 3-epi-25(OH) $\mathrm{D}_{3}$ metabolite and yield an unbiased median result of 29.6 $\mathrm{ng} / \mathrm{mL}$ for $25(\mathrm{OH}) \mathrm{D}_{\text {Total }}$ in SRM 972a L4.

VitDQAP-II (Vial A) also has a significant 3-epi-25(OH)D ${ }_{3}$ concentration of $3.4 \mathrm{ng} / \mathrm{mL} \pm 0.1$ $\mathrm{ng} / \mathrm{mL}$, or $\approx 9 \%$ of the $25(\mathrm{OH}) \mathrm{D}_{3}$ concentration of $37.0 \mathrm{ng} / \mathrm{mL} \pm 0.4 \mathrm{ng} / \mathrm{mL}$ (NIST values). In theory, bimodal results should have also been obtained for this material, but the $9 \%$ bias is indistinguishable in the overall method variability of $12 \%$ for the LC results.

Of the nine LC participants that used methods that separate the 3-epi-25(OH) $\mathrm{D}_{3}$, seven reported values for this metabolite in the control and study materials. The LC method results for $25(\mathrm{OH}) \mathrm{D}_{3}$ and 3-epi-25(OH)D 3 are presented and discussed in detail later in this report. 
Figure 1. 25(OH)D Total levels in VitDQAP-II (Vial A) as determined by immunoassay (CLIA and RIA) and LC (LC-MS ${ }^{\mathrm{n}}$ and LCUV) methods. The red lines represent the ranges bound by the NIST values with \pm estimated $U_{95}$ uncertainty.

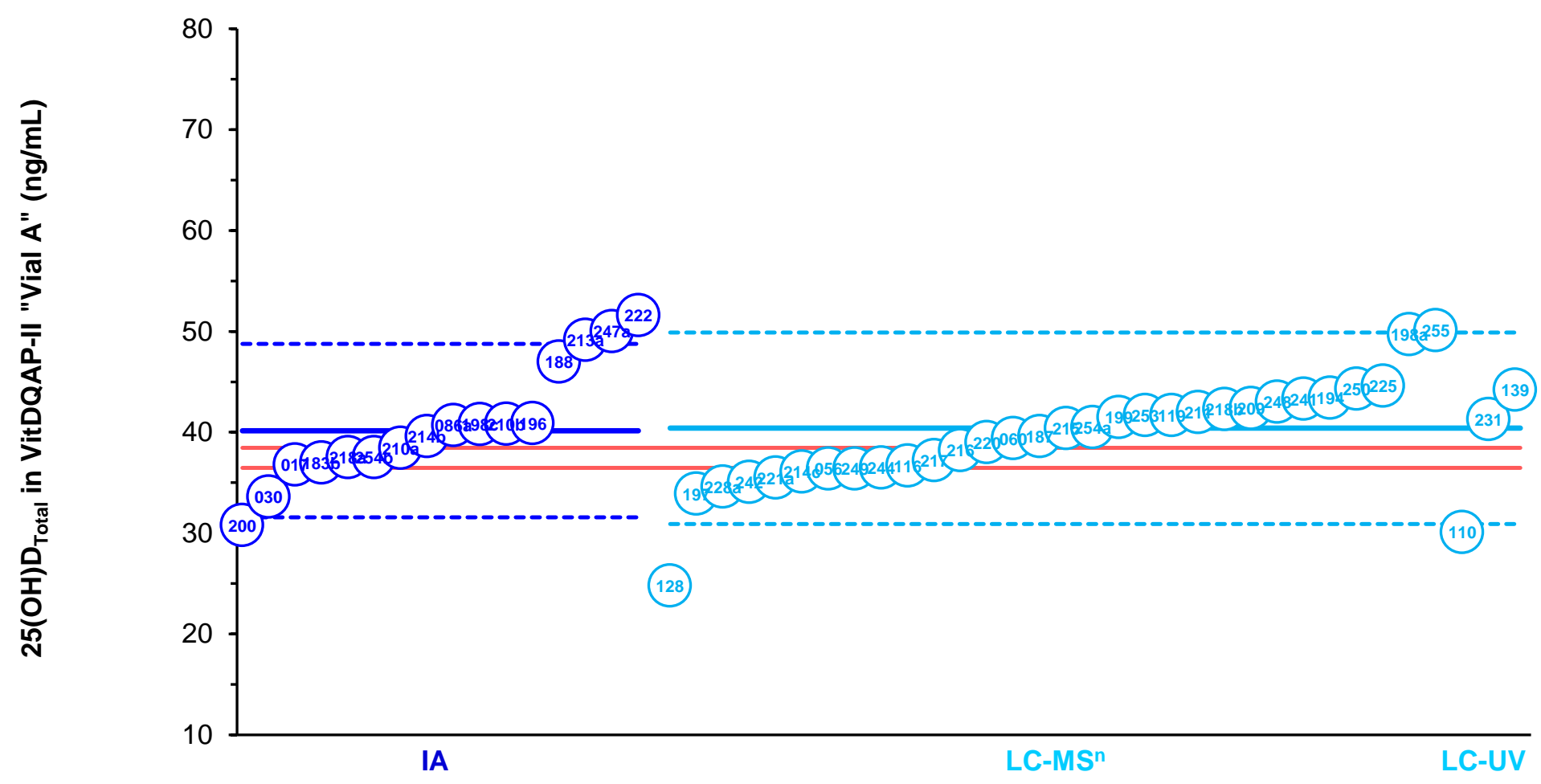

\footnotetext{
IA method laboratory values

IA method consensus range encloses \pm 2 MADe around consensus median

LC method laboratory values

$\overline{----}$ LC method consensus range encloses \pm 2 MADe around consensus median

— NIST value range encloses approx. 95\% confidence uncertainty
} 
Figure 2. $25(\mathrm{OH}) \mathrm{D}_{\text {Total }}$ levels in SRM 972a L4 (Vial B) as determined by immunoassay (CLIA and RIA) and LC (LC-MS ${ }^{\mathrm{n}}$ and LCUV) methods. The red lines represent the ranges bound by the NIST values with \pm estimated $U_{95}$ uncertainty.

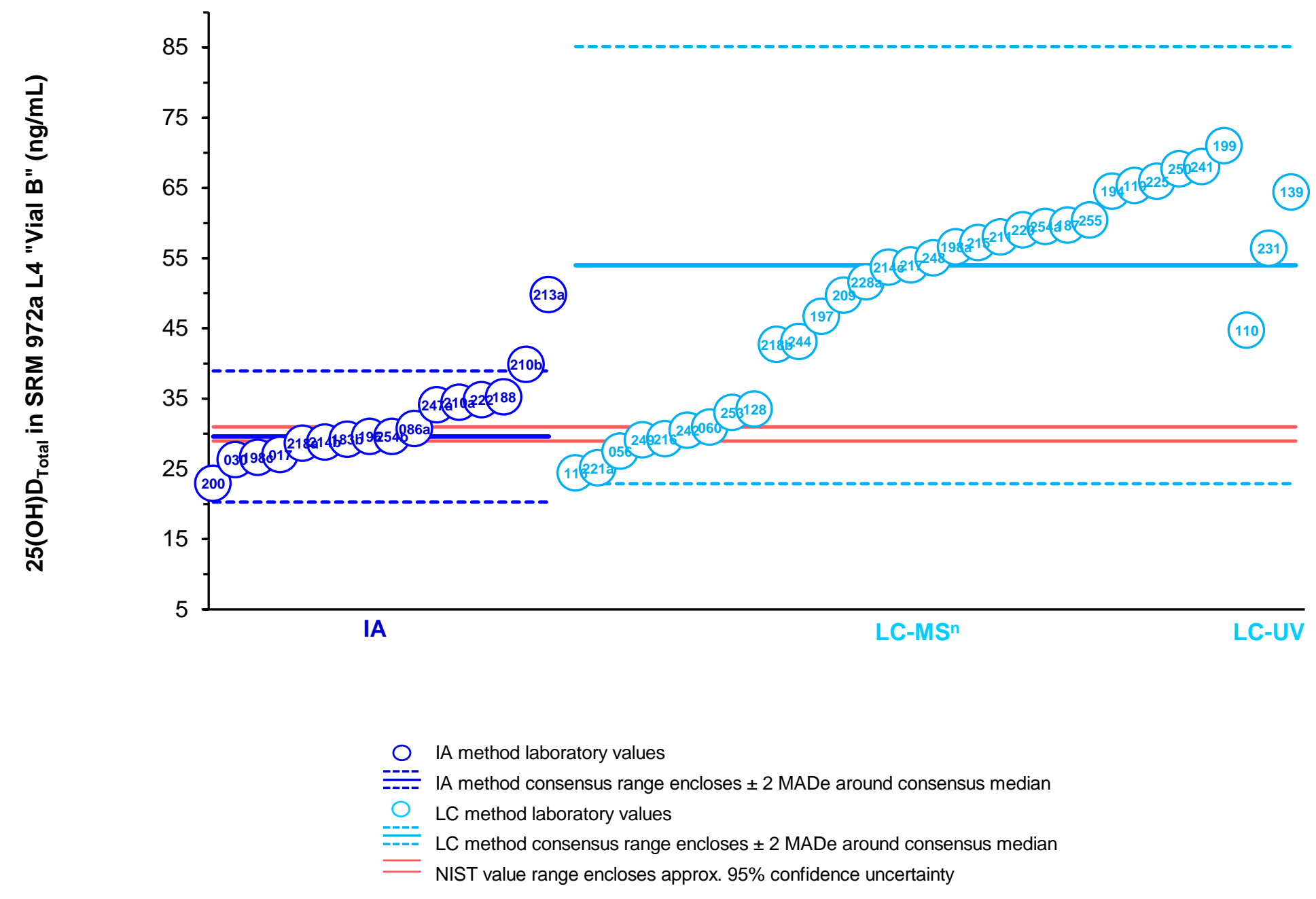


Figure 3. $25(\mathrm{OH}) \mathrm{D}_{\text {Total }}$ levels in SRM 968d L1 (Control) as determined by immunoassay (CLIA and RIA) and LC (LC-MS ${ }^{\mathrm{n}}$ and LCUV) methods. The red lines represent the ranges bound by the NIST values with \pm estimated $U_{95}$ uncertainty.

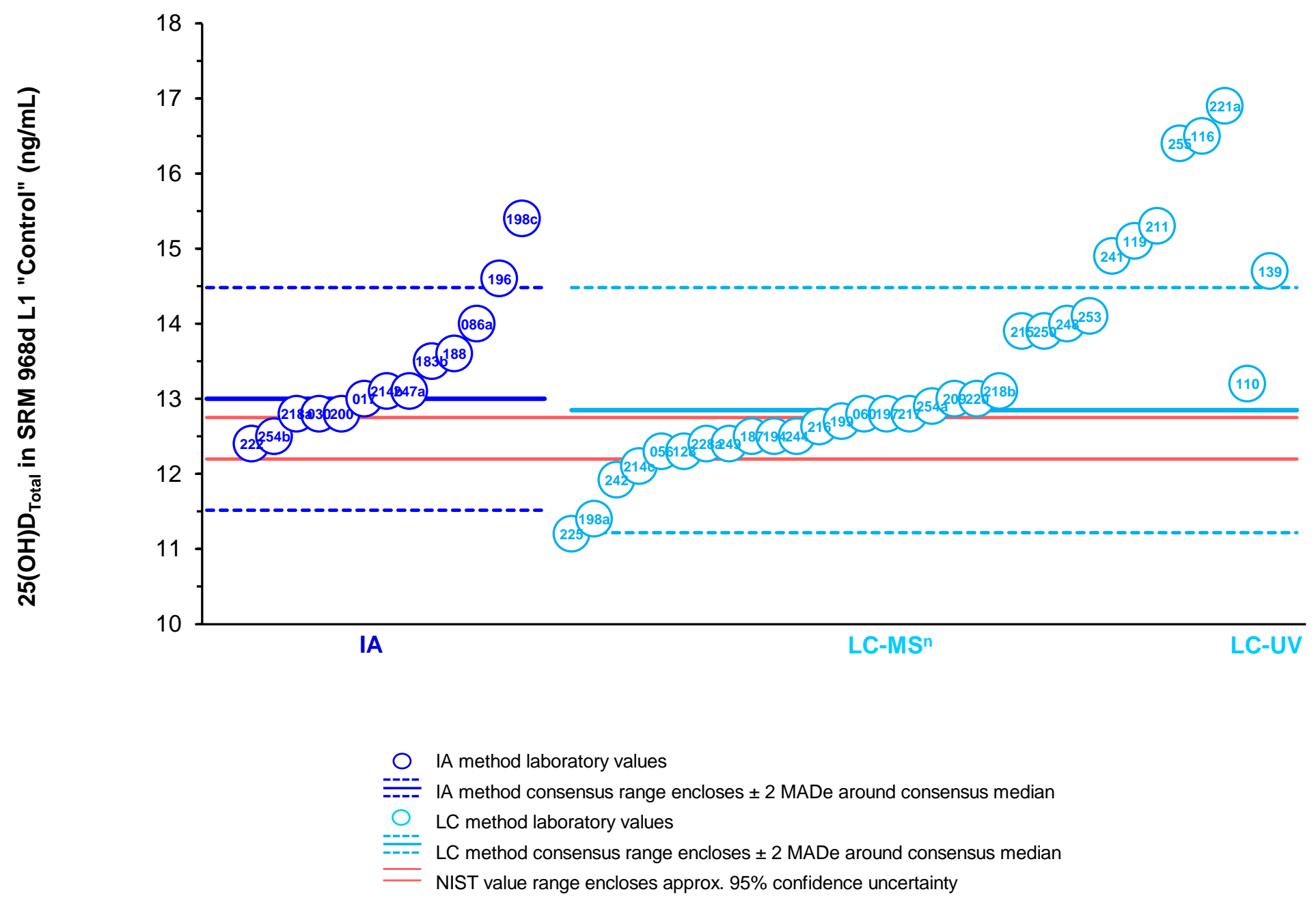


Figure 4 presents direct graphical comparisons of the $25(\mathrm{OH}) \mathrm{D}_{\text {Total }}$ results for A) VitDQAP-II (Vial A) and SRM 972a L4 (Vial B), and B) SRM 972a L4 (Vial B) and SRM 968d L1

(Control). In each plot, there are two blue consensus boxes, one for IA methods and one for LC methods (as indicated). Laboratory results that are within the consensus range for both study materials are within the blue consensus boxes. Conversely, laboratory results that fall outside of (or on the edge of) either of the consensus boxes are not included in the consensus ranges and are highlighted with their laboratory code numbers. In each plot, the NIST values for the materials are denoted with a red diamond symbol $(\diamond)$, and the Youden line $(\mathrm{y}=\mathrm{x})$ centered on the NIST value is illustrated by a red line (-) across the magnitude of the $\mathrm{y}$-axis and $\mathrm{x}$-axis, respectively.

Specific results as assessed from the Youden comparison plots are summarized below.

VitDQAP-II (Vial A) and SRM 972a L4 (Vial B): Figure 4 A

- Laboratory results that are not included in the consensus ranges include numbers 110,128 , 200, 210b, 213a, 222, and 247a

- The Youden line runs through the center of the IA consensus box and through the bottom corner of the LC consensus box for these materials, illustrating that the IA results are in better agreement with the NIST results for these materials.

- Most of the LC results for SRM 972a L4 are higher than both the Youden line and the IA consensus box; however, the LC box overlaps both the Youden line and the IA consensus box because the LC consensus box is very large in the SRM 972a L4 dimension (y-axis).

SRM 972a L4 (Vial B) and SRM 968d L1 (Control): Figure 4 B

- Laboratory results that are not included in the consensus ranges include numbers 116,119 , 139, 196, 198c, 210a, 211, 213a, 221a, 241, and 255

- The Youden line runs through the center of the IA consensus box and through the left corner of the LC consensus box for these materials, illustrating that the IA results are in better agreement with the NIST results for these materials.

- Most of the LC results for SRM 972a L4 are higher than both the Youden line and the IA consensus box; however, the LC box overlaps both the Youden line and the IA consensus box because the LC consensus box is very large in the SRM 972a L4 dimension (x-axis).

Both of these Youden plots involving SRM 972a L4 (Vial B) reveal separation of the IA results and the majority of the LC results, further illustrating the difference in results for the two techniques for the material with high levels of 3-epi-25(OH)D 3 . 
Figure 4. Youden comparison plot of the results for $25(\mathrm{OH}) \mathrm{D}_{\text {Total }}$ in A) VitDQAP-II (Vial A) and SRM 972a L4 (Vial B) and

B) 972a L4 (Vial B) and SRM 968d L1 (Control) for all methods
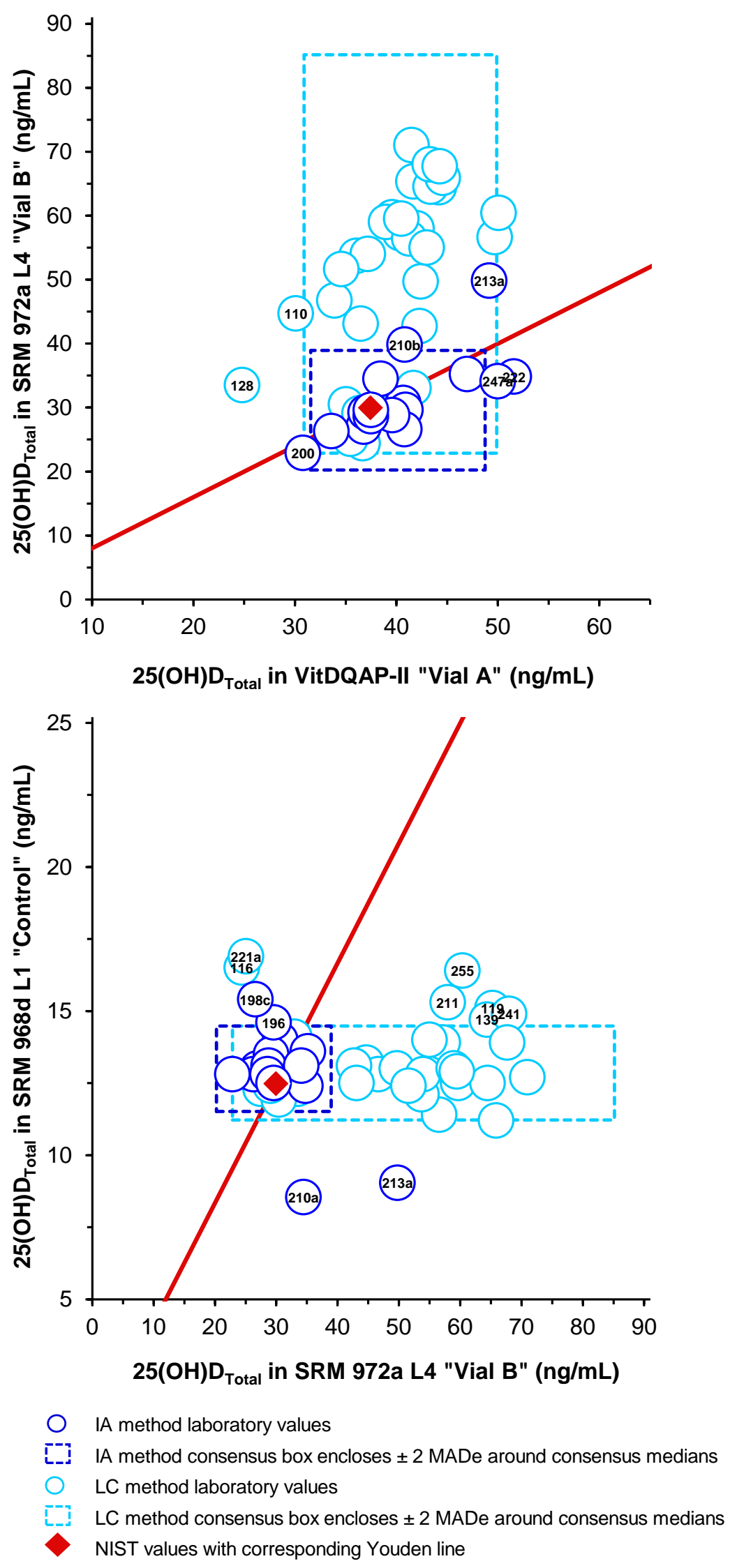


\section{5(OH)D $\mathrm{D}_{3}$ and 3-epi-25(OH)D 3 in VitDQAP-II (Vial A), SRM 972a L4 (Vial B), and SRM 968d L1 (Control): LC methods only}

Of the two major techniques IA and LC, only the LC methods can independently measure the $25(\mathrm{OH}) \mathrm{D}_{2}$ and $25(\mathrm{OH}) \mathrm{D}_{3}$ components of $25(\mathrm{OH}) \mathrm{D}_{\text {Total }}$, and therefore $\mathrm{LC}$ methods require accurate, unbiased measurements of both $25(\mathrm{OH}) \mathrm{D}_{2}$ and $25(\mathrm{OH}) \mathrm{D}_{3}$ to obtain the correct values for $25(\mathrm{OH}) \mathrm{D}_{\text {Total. }}$. The $25(\mathrm{OH}) \mathrm{D}_{2}$ metabolite does not contribute significantly to the $25(\mathrm{OH}) \mathrm{D}_{\text {Total }}$ in either of the two study materials or the control. However, both VitDQAP-II (Vial A) and SRM 972a L4 (Vial B) contain significant concentrations of the 3-epi-25(OH) $\mathrm{D}_{3}$ metabolite. Therefore, the 3 -epi- $25(\mathrm{OH}) \mathrm{D}_{3}$ needs to be separated from $25(\mathrm{OH}) \mathrm{D}_{3}$ to avoid a significant measurement bias.

In the Summer 2013 comparability study, all but one of the LC participants reported values for $25(\mathrm{OH}) \mathrm{D}_{3}$, and the reported values are summarized in Table 2.

Of the $33 \mathrm{LC}$ participants, nine used methods that separated the 3 -epi- $25(\mathrm{OH}) \mathrm{D}_{3}$ interference from $25(\mathrm{OH}) \mathrm{D}_{3}$ (Appendix A-2, A-3). Of those nine, seven participants reported values for 3epi-25(OH) $\mathrm{D}_{3}$ in the study samples and in the control, and the results are summarized in Table 3.

For both Table 2 and Table 3 , the community results are summarized at the bottom of the table for all LC methods and for the LC-MS methods only. These summarized results include $\mathrm{N}$, the median value, the MADe, and the CV\%. Table 2 and Table 3 also present the NIST values and the $95 \%$ confidence limits $\left(U_{95}\right)$ for $25(\mathrm{OH}) \mathrm{D}_{3}$ and 3 -epi- $25(\mathrm{OH}) \mathrm{D}_{3}$, respectively, in the study and control materials.

For the participant results for SRM 972a L4 (Vial B), the consensus variability is large for $25(\mathrm{OH}) \mathrm{D}_{3}(30 \%)$. The source of the measurement uncertainty for $25(\mathrm{OH}) \mathrm{D}_{3}$ is the wideranging, bimodal results from labs that separate the 3 -epi- $25(\mathrm{OH}) \mathrm{D}_{3}$ and those that do not. However, the results for the seven participants that measure 3-epi-25(OH) $\mathrm{D}_{3}$ exhibit relatively low variability for VitDQAP-II (Vial A) and SRM 972a L4 (Vial B) with a CV $\approx 8 \%$. 
Table 2. Summary of LC participant data and community results for $25(\mathrm{OH}) \mathrm{D}_{3}(\mathrm{ng} / \mathrm{mL})$ in the study samples and control.

\begin{tabular}{|c|c|c|c|c|}
\hline $\mathrm{Lab}$ & Method & Vial A & Vial B & Control \\
\hline 056 & LC-MS/MS & 35.8 & 26.8 & 12.1 \\
\hline 060 & LC-MS/MS & 39.4 & 30.9 & 12.8 \\
\hline 110 & LC-UV & 30.1 & 44.7 & 13.2 \\
\hline 116 & LC-MS/MS & 36.7 & 24.4 & 16.5 \\
\hline 119 & LC-MS/MS & 41.7 & 65.3 & 15.1 \\
\hline 128 & LC-MS/MS & 24.8 & 33.5 & 12.3 \\
\hline 187 & LC-MS/MS & 39.6 & 59.7 & 12.5 \\
\hline 194 & LC-MS/MS & 43.4 & 64.5 & 12.5 \\
\hline 197 & LC-MS/MS & 33.9 & 46.7 & 12.8 \\
\hline $198 a$ & LC-MS/MS & 49.7 & 56.6 & 11.4 \\
\hline 199 & LC-MS/MS & 41.5 & 71.0 & 12.7 \\
\hline 209 & LC-MS/MS & 42.4 & 49.7 & 13.0 \\
\hline 211 & LC-MS/MS & 42.0 & 58.0 & 15.3 \\
\hline $214 c$ & LC-MS/MS & 36.1 & 53.7 & 12.1 \\
\hline 215 & LC-MS/MS & 40.4 & 56.8 & 13.9 \\
\hline 216 & LC-MS/MS & 37.8 & 28.9 & 12.5 \\
\hline 217 & LC-MS/MS & 37.2 & 54.0 & 12.8 \\
\hline $218 b$ & LC-MS/MS & 42.3 & 42.7 & 13.1 \\
\hline 220 & LC-MS/MS & 39.0 & 59.0 & 13.0 \\
\hline $221 a$ & LC-MS/MS & 35.5 & 25.1 & 16.9 \\
\hline 225 & LC-MS/MS & 44.6 & 65.9 & 11.2 \\
\hline $228 a$ & LC-MS/MS & 34.6 & 51.6 & 12.4 \\
\hline 231 & LC-UV & 41.3 & 56.4 & $n / r$ \\
\hline 241 & LC-MS/MS & 43.3 & 68.0 & 14.9 \\
\hline 242 & LC-MS/MS & 35.1 & 30.5 & 11.9 \\
\hline 244 & LC-MS/MS & 36.5 & 43.1 & 12.5 \\
\hline 248 & LC-MS/MS & 42.7 & 55.4 & 14.1 \\
\hline 249 & LC-MS/MS & 36.4 & 29.1 & 12.4 \\
\hline 250 & LC-MS/MS & 44.3 & 67.7 & 13.9 \\
\hline 253 & LC-MS/MS & 41.2 & 32.5 & 13.9 \\
\hline $254 a$ & LC-MS/MS & 40.3 & 59.4 & 12.9 \\
\hline 255 & LC-MS/MS & 49.5 & 59.9 & 16.1 \\
\hline \multirow{4}{*}{ 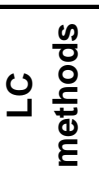 } & $\mathrm{N}$ & 32 & 32 & 31 \\
\hline & Median & 40.0 & 53.9 & 12.8 \\
\hline & MADe & 4.9 & 15.9 & 0.7 \\
\hline & CV\% & 12.2 & 29.5 & 5.8 \\
\hline \multirow{4}{*}{$\sum_{0}^{0}$} & & 29 & 29 & 29 \\
\hline & Median & 40.3 & 54.0 & 12.8 \\
\hline & MADe & 4.6 & 16.8 & 0.7 \\
\hline & CV\% & 11.4 & 31.0 & 5.8 \\
\hline & NIST Value & 37.0 & 29.4 & 12.4 \\
\hline & $U_{95}$ & 0.4 & 0.9 & 0.3 \\
\hline
\end{tabular}


Table 3. Summary of LC participant data and community results for 3-epi-25(OH) $\mathrm{D}_{3}(\mathrm{ng} / \mathrm{mL})$ in the study samples and control.

\begin{tabular}{|c|c|c|c|c|}
\hline & & VitDQAP-II & SRM 972a L4 & SRM 968d L1 \\
\hline Lab & Method & Vial A & Vial B & Control \\
\hline 056 & LC-MS/MS & 3.5 & 24.3 & 1.8 \\
\hline 060 & LC-MS/MS & 3.3 & 28.7 & 0.7 \\
\hline 116 & LC-MS/MS & 5.8 & 27.3 & $<4.0$ \\
\hline 216 & LC-MS/MS & 3.1 & 27.0 & 0.6 \\
\hline 242 & LC-MS/MS & 2.6 & 20.7 & 0.6 \\
\hline 249 & LC-MS/MS & 3.2 & 28.5 & 0.4 \\
\hline 253 & LC-MS/MS & 3.4 & 25.8 & 0.7 \\
\hline n & $\bar{N}$ & 7 & 7 & 6 \\
\hline 0 : & Median & 3.3 & 27.0 & 0.7 \\
\hline ป岳 & MADe & 0.3 & 2.2 & 0.1 \\
\hline & CV\% & 7.6 & 8.2 & 13.6 \\
\hline & $\mathrm{N}$ & 7 & 7 & 6 \\
\hline$\sum^{\infty}$ & Median & 3.3 & 27.0 & 0.7 \\
\hline J & MADe & 0.3 & 2.2 & 0.1 \\
\hline & CV\% & 7.6 & 8.2 & 13.6 \\
\hline & NIST Value & 3.4 & 26.4 & 0.66 \\
\hline & $U_{95}$ & 0.1 & 2.1 & 0.02 \\
\hline
\end{tabular}


Figure 5 and Figure 6 present direct graphical comparisons of the $\mathrm{LC}$ results for $25(\mathrm{OH}) \mathrm{D}_{3}$ and 3-epi-25(OH)D 3 , respectively, for A) VitDQAP-II (Vial A) and SRM 972a L4 (Vial B), and B) SRM 972a L4 (Vial B) and SRM 968d L1 (Control). In each plot, there is one blue consensus box for the LC results. Laboratory results that are within the consensus range for both study materials are within the blue consensus box. Conversely, laboratory results that fall outside of (or on the edge of) the consensus box are not included in the consensus range and are highlighted with their laboratory code numbers. In each plot, the NIST values for the materials are denoted with a red diamond symbol $(\diamond)$, and the Youden line $(\mathrm{y}=\mathrm{x})$ centered on the NIST value is illustrated by a red line (-) across the magnitude of the $y$-axis and $\mathrm{x}$-axis, respectively.

Specific results as assessed from the Youden comparison plots are summarized below.

25(OH)D $D_{3}$ in VitDQAP-II (Vial A) and SRM 972a LA (Vial B): Figure 5 A

- Laboratory results that are not included in the consensus range include numbers 110 and 128.

- The Youden line runs through the cluster of LC results that separate the $25(\mathrm{OH}) \mathrm{D}_{3}$ and 3-epi$25(\mathrm{OH}) \mathrm{D}_{3}$, illustrating the better agreement of these results with the NIST values for these materials.

- Most of the LC results for SRM 972a L4 are higher than the Youden line; however, the Youden line overlaps the bottom of the LC consensus box, which is very large in the SRM 297a L4 dimension (y-axis).

\section{5(OH)D $D_{3}$ in SRM 972a L4 (Vial B) and SRM 968d L1 (Control): Figure 5 B}

- Laboratory results that are not included in the consensus range include numbers 116,119 , 211, 221a, 225, 241, and 255.

- The Youden line runs through the cluster of the LC results that separate the $25(\mathrm{OH}) \mathrm{D}_{3}$ and 3epi-25(OH) $\mathrm{D}_{3}$, illustrating the better agreement of these results with the NIST values for these materials.

- Most of the LC results for SRM 972a L4 are higher than the Youden line; however, the Youden line overlaps the left corner of the LC consensus box, which is very large in the SRM 297a L4 dimension (x-axis).

\section{3-epi-25(OH)D $D_{3}$ in VitDQAP-II (Vial A) and SRM 972a L4 (Vial B): Figure 6 A}

- Laboratory results that are not included in the consensus range include numbers 116 and 242.

- The Youden line runs through the center of the consensus box, indicating good agreement of the LC results with the NIST values for these materials.

\section{3-epi-25(OH)D $D_{3}$ in SRM 972a L4 (Vial B) and SRM 968d L1 (Control): Figure 6 B}

- Only three of the laboratory results are included in the consensus range for these materials because of the variability of the results for SRM 968d L1 (y-axis).

- The Youden line runs through the center of the consensus box, indicating good agreement of the LC results with the NIST values for these materials even with the higher variability of results for SRM 968d L1 (y-axis). 
Figure 5. Youden comparison plot of the results for $25(\mathrm{OH}) \mathrm{D}_{3}$ in A) VitDQAP-II (Vial A) and SRM 972a L4 (Vial B) and B) SRM 972a L4 (Vial B) and SRM 968d L1 (Control) for LC methods.
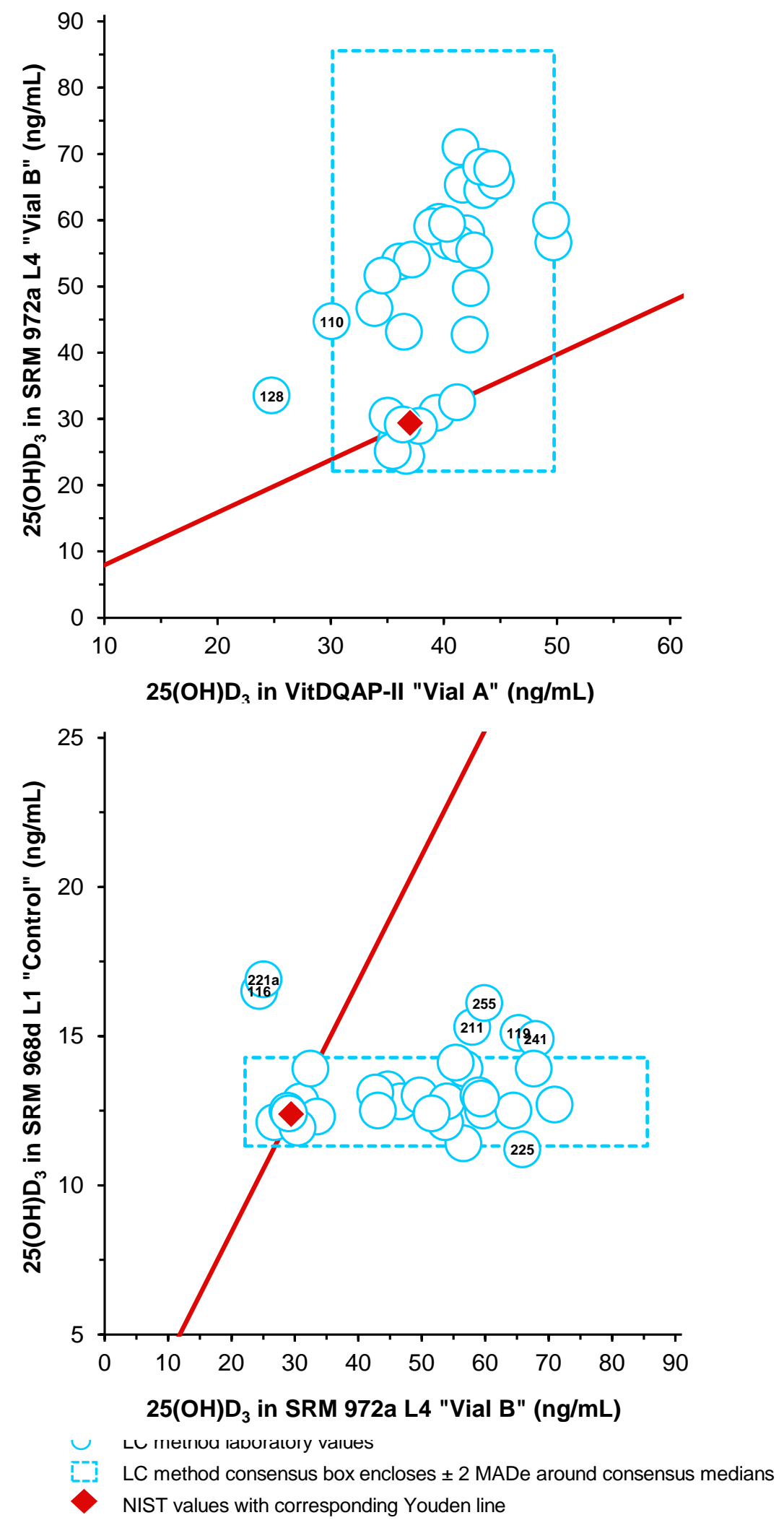
Figure 6. Youden comparison plot of the results for 3-epi-25(OH)D 3 in A) VitDQAP-II (Vial A) and SRM 972a L4 (Vial B) and B) SRM 972a L4 (Vial B) and SRM 968d L1 (Control) for LC methods.
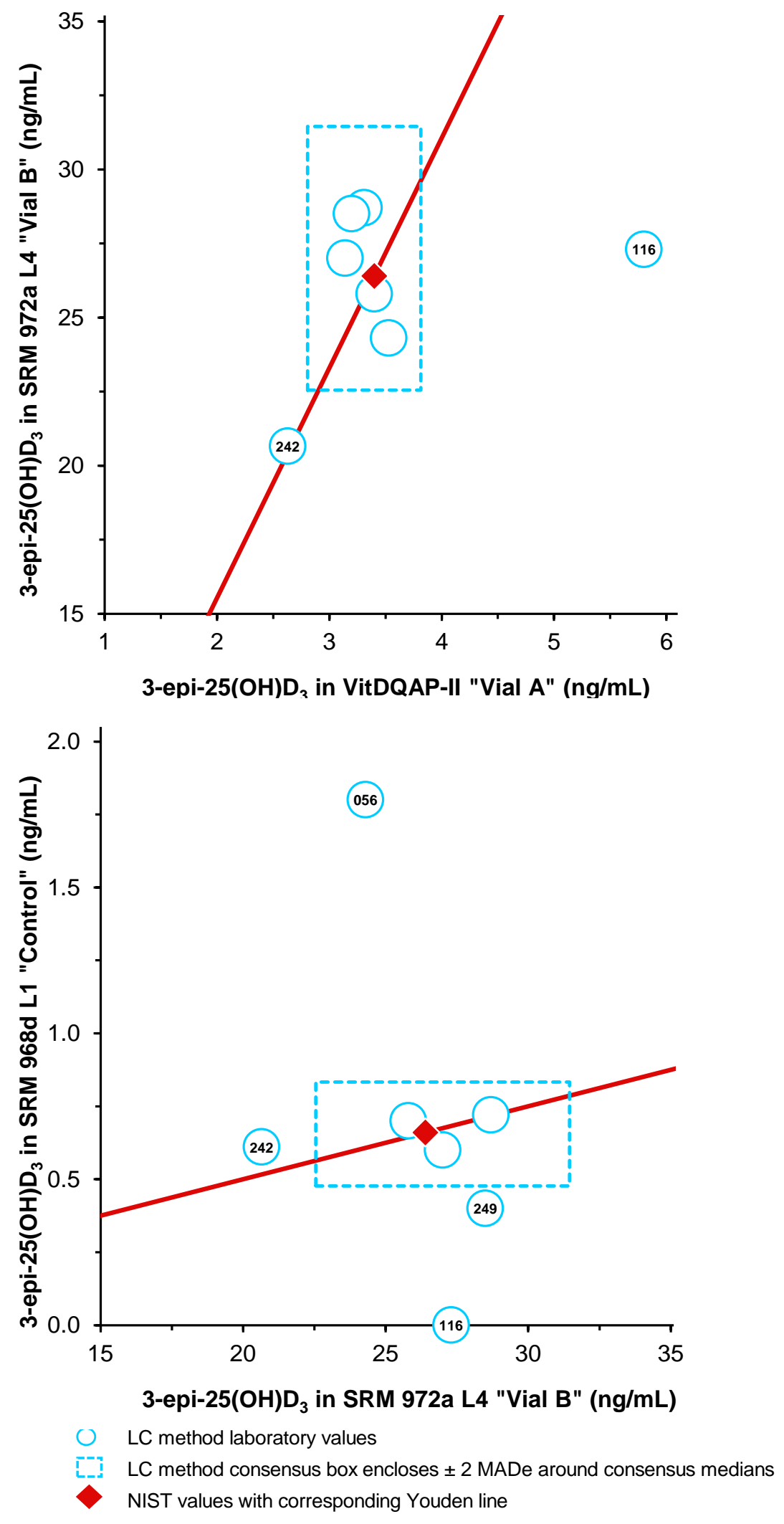


\section{Conclusions from the Summer 2013 Comparability Study of the VitDQAP}

In the six previous comparability studies of the VitDQAP, participant performance was consistent for study materials that contain predominantly $25(\mathrm{OH}) \mathrm{D}_{3}$; the $\mathrm{CV}$ was in the range from $7 \%$ to $19 \%$, and the median values were biased slightly high relative to the NIST values. In the Summer 2013 comparability study, both VitDQAP-II (Vial A) and SRM 968d L1 (Control) also contain predominantly $25(\mathrm{OH}) \mathrm{D}_{3}$. The participant results for VitDQAP-II (Vial A) and SRM 968d L1 (Control) had a CV of $12 \%$ and $7 \%$, respectively, and the all-method median values were biased slightly high relative to the NIST values, indicating the performance for these two materials is comparable to similar materials previously evaluated in the VitDQAP.

For SRM 972a L4 (Vial B), however, which contained similar concentrations of both $25(\mathrm{OH}) \mathrm{D}_{3}$ and 3-epi-25(OH) $\mathrm{D}_{3}$, the results were not comparable. The majority of the LC methods did not separate the 3-epi-25(OH)D $\mathrm{D}_{3}$ interference from the $25(\mathrm{OH}) \mathrm{D}_{3}$ measurement and obtained results for $25(\mathrm{OH}) \mathrm{D}_{\text {Total }}$ that were biased significantly high, which led to the largest all-method $\mathrm{CV}$ $(47 \%)$ to date for any material evaluated in the VitDQAP. While VitDQAP-II (Vial A) also contained a measureable amount of 3-epi-25(OH)D 3 and should have produced similar results, the 3-epi-25(OH)D 3 was low enough $(\approx 3.4 \mathrm{ng} / \mathrm{mL})$ that the bias was not observable in the overall method CV of $12 \%$ for that study material. Participants that use LC methods are encouraged to utilize chromatographic conditions and columns that separate the 3-epi-25(OH) $\mathrm{D}_{3}$ interference to eliminate this potential measurement bias. 
Appendix A-1. Summary of immunoassay methods used by participants.

\begin{tabular}{|c|c|c|c|}
\hline $\begin{array}{c}\text { Laboratory } \\
\text { Number }\end{array}$ & IA Method & Sample Preparation & Vendor/kit \\
\hline 17 & CLIA & $\mathrm{n} / \mathrm{r}$ & A \\
\hline 30 & RIA & Samples were extracted with acetonitrile & $\mathrm{D}$ \\
\hline $86 a$ & CLIA & $\mathrm{n} / \mathrm{r}$ & A \\
\hline $183 b$ & CLIA & $\mathrm{n} / \mathrm{r}$ & A \\
\hline 188 & CLIA & None & $B$ \\
\hline 196 & CLIA & The human serum samples were analyzed neat & A \\
\hline $198 \mathrm{c}$ & CLIA & $\mathrm{n} / \mathrm{r}$ & $\mathrm{n} / \mathrm{r}$ \\
\hline 200 & RIA & $\mathrm{n} / \mathrm{r}$ & $\bar{D}$ \\
\hline $210 a$ & RIA & Sample was extracted with acetonitrile & $\mathrm{D}$ \\
\hline $210 b$ & CLIA & $\mathrm{n} / \mathrm{r}$ & C \\
\hline $213 a$ & CLIA & Sample was thawed and gently mixed prior to analysis & $\mathrm{C}$ \\
\hline $214 \mathrm{~b}$ & CLIA & $\mathrm{n} / \mathrm{r}$ & $\mathrm{n} / \mathrm{r}$ \\
\hline $218 a$ & CLIA & Direct analysis & $\mathrm{n} / \mathrm{r}$ \\
\hline 222 & CLIA & $\mathrm{n} / \mathrm{r}$ & $\mathrm{B}$ \\
\hline $247 a$ & CLIA & Sample was thawed, mixed well and used in the assay & B \\
\hline $254 b$ & CLIA & $\mathrm{n} / \mathrm{r}$ & A \\
\hline
\end{tabular}

$\mathrm{n} / \mathrm{r}=$ not reported

*NIST cannot endorse or recommend commercial products, so individual vendors/kits are indicated with a unique letter but not identified 
Appendix A-2. Summary of LC-MS ${ }^{\mathrm{n}}$ methods reported by participants.

\begin{tabular}{|c|c|c|c|c|}
\hline $\begin{array}{l}\text { Laboratory } \\
\text { Number }\end{array}$ & $\begin{array}{c}\text { Internal } \\
\text { Standard (IS) }\end{array}$ & Sample Preparation & Chromatographic Conditions & Detection: MRM ions \\
\hline 56 & $\begin{array}{c}25(\mathrm{OH}) \mathrm{D}_{2}-d_{3} \\
25(\mathrm{OH}) \mathrm{D}_{3}-d_{6} \\
\text { 3-epi-25(OH) } \mathrm{D}_{3}-d_{3}\end{array}$ & $\begin{array}{l}\text { Samples were extracted with } \\
\text { hexane, evaporated, then } \\
\text { reconstituted with } 69 \% \text { methanol }\end{array}$ & $\begin{array}{l}\text { PFP column ( } 100 \times 2.1 \mathrm{~mm} ; 1.9 \\
\mu \mathrm{m}) \text {; isocratic elution; flow } 0.4 \\
\mathrm{~mL} / \mathrm{min}\end{array}$ & $\begin{array}{l}25(\mathrm{OH}) \mathrm{D}_{3} 383 / 365 \\
25(\mathrm{OH}) \mathrm{D}_{3}-d_{6} 389 / 371 \\
25(\mathrm{OH}) \mathrm{D}_{2} 395 / 377 \\
25(\mathrm{OH}) \mathrm{D}_{2}-d_{3} 398 / 380 \\
3-\text { epi-25(OH) } \mathrm{D}_{3} 383 / 365\end{array}$ \\
\hline 60 & $25(\mathrm{OH}) \mathrm{D}_{3}-d_{6}$ & $\begin{array}{l}\text { IS was added, and then samples } \\
\text { were extracted with acetonitrile, } \\
\text { evaporated, and reconstituted } \\
\text { with } 80 \% \text { methanol } / 20 \% \text { water }\end{array}$ & $\begin{array}{l}\text { PFP column }(100 \times 3.0 \mathrm{~mm} ; 2.6 \\
\mu \mathrm{m}) ; \text { gradient with water, methanol } \\
\text { and acetonitrile }(0.05 \% \text { formic acid })\end{array}$ & $\begin{array}{l}25(\mathrm{OH}) \mathrm{D}_{3} 383 / 211 \\
25(\mathrm{OH}) \mathrm{D}_{2} 413 / 355 \\
\text { 3-epi-25(OH)D3 401/383 }\end{array}$ \\
\hline 116 & $25(\mathrm{OH}) \mathrm{D}_{3}-d_{6}$ & $\begin{array}{l}\text { Serum proteins were precipitated } \\
\text { with methanol }\end{array}$ & $\begin{array}{l}\text { Online SPE; reversed-phase } \\
\text { column; isocratic elution with } 95 \% \\
\text { methanol } / 5 \% \text { water; flow } 0.6 \mathrm{~mL} / \mathrm{min}\end{array}$ & $\begin{array}{l}25(\mathrm{OH}) \mathrm{D}_{3} 383 / 211 \\
25(\mathrm{OH}) \mathrm{D}_{3}-d_{6} 389 / 211 \\
25(\mathrm{OH}) \mathrm{D}_{2} 395 / 269\end{array}$ \\
\hline 119 & $25(\mathrm{OH}) \mathrm{D}_{3}-d_{6}$ & $\begin{array}{l}\text { Samples mixed with ethanol } \\
\text { containing the IS, equilibrated, } \\
\text { mixed, extracted with hexane, } \\
\text { evaporated, and reconstituted in } \\
\text { mobile phase }\end{array}$ & $\begin{array}{l}\text { C18 column }(150 \times 3.0 \mathrm{~mm} ; 2.7 \\
\mu \mathrm{m}) ; \text { Gradient with water and } \\
\text { methanol }(0.1 \% \text { formic acid })\end{array}$ & $\begin{array}{l}25(\mathrm{OH}) \mathrm{D}_{3} 401 / 383 \\
25(\mathrm{OH}) \mathrm{D}_{3}-d_{6} 407 / 371 \text { and } \\
407 / 389 ; \\
25(\mathrm{OH}) \mathrm{D}_{2} 395 / 209 \text { and } \\
395 / 251\end{array}$ \\
\hline 128 & $n / r$ & $n / r$ & $n / r$ & $n / r$ \\
\hline 187 & $\mathrm{n} / \mathrm{r}$ & SPE & C18 column $(50 \times 2.1 \mathrm{~mm} ; 3 \mu \mathrm{m})$ & $\begin{array}{l}25(\mathrm{OH}) \mathrm{D}_{2} 413 / 395 \\
25(\mathrm{OH}) \mathrm{D}_{3} 401 / 383\end{array}$ \\
\hline 194 & $25(\mathrm{OH}) \mathrm{D}_{3}-d_{6}$ & $\begin{array}{l}\text { Proteins precipitated with } \\
\text { acetonitrile, top layer removed, } \\
\text { evaporated, and reconstituted } \\
\text { with methanol }\end{array}$ & $\begin{array}{l}\text { C8 column }(50 \times 2 \mathrm{~mm}) \text {; isocratic } \\
\text { elution with } 70 \% \text { acetonitrile/ } 30 \% \\
\text { water; flow } 0.7 \mathrm{~mL} / \mathrm{min}\end{array}$ & $\begin{array}{l}25(\mathrm{OH}) \mathrm{D}_{2} 395 / 119 \\
25(\mathrm{OH}) \mathrm{D}_{3} 383 / 211\end{array}$ \\
\hline 197 & $25(\mathrm{OH}) \mathrm{D}_{3}-d_{6}$ & $\begin{array}{l}\text { Precipitating agent added ( } 200 \mu \mathrm{L} \\
\text { with } 20 \mathrm{ng} \mathrm{IS}) \text { to each serum ( } 200 \\
\mu \mathrm{L}), \text { calibrator and control sample } \\
\text { followed by mixing, centrifugation, } \\
\text { and analysis }\end{array}$ & $\begin{array}{l}\text { C18 column }(50 \times 4.6 \mathrm{~mm} ; 5 \mu \mathrm{m}) \text {; } \\
\text { column temp } 45^{\circ} \mathrm{C} \text {; gradient with } \\
\text { water and methanol; flow } 1.0 \\
\mathrm{~mL} / \mathrm{min}\end{array}$ & $\mathrm{n} / \mathrm{r}$ \\
\hline $198 a$ & $25(\mathrm{OH}) \mathrm{D}_{3}-d_{6}$ & $\begin{array}{l}\text { Proteins precipitated with } \\
\text { methanol, followed by hexane } \\
\text { extraction, centrifugation, } \\
\text { evaporation under } \mathrm{N}_{2} \text {, and } \\
\text { reconstitution in methanol }(0.1 \% \\
\text { formic acid) }\end{array}$ & $\begin{array}{l}\text { C18 column }(50 \times 2.1 \mathrm{~mm} ; 3.5 \mu \mathrm{m}) \\
\text { isocratic elution with } 85 \% \text { methanol } \\
(0.1 \% \text { formic acid }) ; \text { flow } 0.5 \mathrm{~mL} / \mathrm{min}\end{array}$ & $\begin{array}{l}25(\mathrm{OH}) \mathrm{D}_{3} 401 / 383,401 / 365 ; \\
25(\mathrm{OH}) \mathrm{D}_{2} 413 / 395,413 / 355 ; \\
25(\mathrm{OH}) \mathrm{D}_{3}-d_{6} 407 / 389 \\
407 / 371\end{array}$ \\
\hline 199 & $n / r$ & $n / r$ & $n / r$ & $\mathrm{n} / \mathrm{r}$ \\
\hline 209 & $25(\mathrm{OH}) \mathrm{D}_{3}-d_{6}$ & $\begin{array}{l}\text { Proteins were precipitated with } \\
\mathrm{ZnSO}_{4} \text { in methanol }\end{array}$ & $\begin{array}{l}\text { C8 column }(50 \times 2 \mathrm{~mm} ; 5 \mu \mathrm{m}) \text {; } \\
\text { gradient with water/methanol; flow } \\
0.7 \mathrm{~mL} / \mathrm{min}\end{array}$ & $\begin{array}{l}25(\mathrm{OH}) \mathrm{D}_{3} 383 / 229,383 / 211 \\
25(\mathrm{OH}) \mathrm{D}_{3}-d_{6} 389 / 211 \\
25(\mathrm{OH}) \mathrm{D}_{2} 395 / 269,395 / 119\end{array}$ \\
\hline 211 & $25(\mathrm{OH}) \mathrm{D}_{3}-d_{6}$ & $\begin{array}{l}\text { Proteins precipitated with } \\
\text { acetonitrile containing IS followed } \\
\text { by centrifugation }\end{array}$ & $\begin{array}{l}\text { Turbulent flow column }(32 \times 4.6 \\
\mathrm{mm} ; 3 \mu \mathrm{m})\end{array}$ & $\begin{array}{l}25(\mathrm{OH}) \mathrm{D}_{3} 383 / 365 \text { (quant), } \\
383 / 257 \text { (qual); } 25(\mathrm{OH}) \mathrm{D}_{2} \\
395 / 209 \text { (quant), 395/377 } \\
\text { (qual) }\end{array}$ \\
\hline $214 c$ & $25(\mathrm{OH}) \mathrm{D}_{3}-d_{6}$ & $\begin{array}{l}\text { Samples were extracted with } \\
\text { hexane, centrifuged, evaporated, } \\
\text { and filtered }\end{array}$ & $\begin{array}{l}\text { Column }(50 \times 2.1 \mathrm{~mm}) \text {; isocratic } \\
\text { elution with } 85 \% \text { methanol } / 15 \% \\
\text { water } 0.1 \% \text { formic acid; flow } 0.3 \\
\mathrm{~mL} / \mathrm{min}\end{array}$ & $\begin{array}{l}25(\mathrm{OH}) \mathrm{D}_{3} 401 / 383 \\
25(\mathrm{OH}) \mathrm{D}_{3}-d_{6} 407 / 389 \\
25(\mathrm{OH}) \mathrm{D}_{2} 413 / 395\end{array}$ \\
\hline 215 & $25(\mathrm{OH}) \mathrm{D}_{3}-d_{6}$ & $\begin{array}{l}\text { Protein precipitation with } \\
\text { methanol/isopropanol and } \mathrm{ZnSO}_{4} \\
\text { supernatant extracted using SPE }\end{array}$ & $\begin{array}{l}\text { C18 column }(50 \times 2.1 \mathrm{~mm} ; 2.6 \mu \mathrm{m}) \\
\text { column; gradient with water }(0.1 \% \\
\text { formic acid, } 5 \mathrm{mmol} / \mathrm{L} \text { ammonium } \\
\text { formate }) \text { and methanol }(0.05 \% \\
\text { formic acid) }\end{array}$ & $\begin{array}{l}25(\mathrm{OH}) \mathrm{D}_{3} 401 / 383 \\
25(\mathrm{OH}) \mathrm{D}_{2} 413 / 395 \\
25(\mathrm{OH}) \mathrm{D}_{3}-d_{6} 407 / 389\end{array}$ \\
\hline
\end{tabular}




\begin{tabular}{|c|c|c|c|c|}
\hline 216 & $\begin{array}{l}\text { Derivatized } \\
\text { deuteriated } \\
\text { standard }\end{array}$ & $\begin{array}{l}\text { Samples extracted using liquid- } \\
\text { liquid extraction then labeled with } \\
\text { a derivatization reagent }\end{array}$ & $\begin{array}{l}\text { Revered-phase column ( } 150 \times 2.1 \\
\mathrm{~mm}) ; \text { gradient from } 25 \% \text { water } \\
(0.05 \% \text { formic acid) to } 50 \% \\
\text { acetonitrile }(0.05 \% \text { formic acid }) ; \\
\text { flow } 0.2 \mathrm{~mL} / \mathrm{min}\end{array}$ & $\mathrm{n} / \mathrm{r}$ \\
\hline 217 & $25(\mathrm{OH}) \mathrm{D}_{3}-d_{6}$ & $\begin{array}{l}\text { Protein precipitation with } \mathrm{ZnSO}_{4} \text { in } \\
\text { methanol followed by SPE }\end{array}$ & $\begin{array}{l}\text { C8 column }(50 \times 2.1 \mathrm{~mm} ; 1.7 \mu \mathrm{m}) \text {; } \\
\text { gradient of } 70 \% \text { to } 98 \% \text { methanol } \\
\text { (with } 0.1 \% \text { formic acid); flow } 0.4 \\
\mathrm{~mL} / \mathrm{min}\end{array}$ & $\begin{array}{l}25(\mathrm{OH}) \mathrm{D}_{3} 401 / 159 \text { (quant), } \\
401 / 383 \text { (qual); } 25(\mathrm{OH}) \mathrm{D}_{2} \\
413 / 83 \text { (quant), } 413 / 395 \\
\text { (qual) }\end{array}$ \\
\hline $218 b$ & $\begin{array}{c}25(\mathrm{OH}) \mathrm{D}_{2}-d_{3} \text { and } \\
25(\mathrm{OH}) \mathrm{D}_{3}-d_{3}\end{array}$ & $\begin{array}{l}\text { Sample was extracted, filtered, } \\
\text { centrifuged, etc. }\end{array}$ & $\begin{array}{l}\text { Phenyl column }(50 \times 2.1 \mathrm{~mm} ; 1.7 \\
\mu \mathrm{m}) \text {; flow } 0.45 \mathrm{~mL} / \mathrm{min}\end{array}$ & $\begin{array}{l}25(\mathrm{OH}) \mathrm{D}_{3} 401 \\
25(\mathrm{OH}) \mathrm{D}_{2} 413\end{array}$ \\
\hline 220 & $\begin{array}{c}25(\mathrm{OH}) \mathrm{D}_{2}-d_{3} \text { and } \\
25(\mathrm{OH}) \mathrm{D}_{3}-d_{6}\end{array}$ & $\begin{array}{l}\text { Protein crash with } 90 \% \text { methanol, } \\
10 \% \mathrm{ZnSO}_{4} \text { and then acetonitrile } \\
(1 \% \text { formic acid); sample filtered } \\
\text { then phospholipids removed with } \\
\text { SPE }\end{array}$ & $\begin{array}{l}\text { C18 column }(20 \times 2.1 \mathrm{~mm}, 2.7 \mu \mathrm{m}) \\
\text { gradient with water and acetonitrile; } \\
\text { flow } 1 \mathrm{~mL} / \mathrm{min} \text {; column } 40{ }^{\circ} \mathrm{C}\end{array}$ & $\begin{array}{l}\text { MRM with dehydrated } \\
\text { precursor and product ions }\end{array}$ \\
\hline $221 a$ & $25(\mathrm{OH}) \mathrm{D}_{3}-d_{6}$ & $\begin{array}{l}\text { Protein crash with } 1 \% \text { methanol in } \\
\text { acetonitrile containing IS }\end{array}$ & $\begin{array}{l}\mathrm{CN} \text { column }(50 \times 3.0 \mathrm{~mm} ; 1.8 \mu \mathrm{m}) \\
\text { methanol/water gradient at } 50^{\circ} \mathrm{C}\end{array}$ & $\begin{array}{l}25(\mathrm{OH}) \mathrm{D}_{3} 383 / 211 ; \\
25(\mathrm{OH}) \mathrm{D}_{3}-d_{6} 389 / 211 ; \\
25(\mathrm{OH}) \mathrm{D}_{2} 395 / 209\end{array}$ \\
\hline 225 & $\mathrm{n} / \mathrm{r}$ & $\mathrm{n} / \mathrm{r}$ & $\mathrm{n} / \mathrm{r}$ & $\mathrm{n} / \mathrm{r}$ \\
\hline $228 a$ & $\begin{array}{l}\text { D8-labeled } \\
\text { compound }\end{array}$ & Proteins precipitated & $\mathrm{n} / \mathrm{r}$ & $\mathrm{n} / \mathrm{r}$ \\
\hline 241 & $25(\mathrm{OH}) \mathrm{D}_{3}-d_{6}$ & $\begin{array}{l}\text { Acetonitrile containing the IS ( } 100 \\
\mu \mathrm{L} \text { ) added to sample }(50 \mu \mathrm{L}) \text { to } \\
\text { precipate proteins, followed by } \\
\text { mixing, sonication, and } \\
\text { centrifugation }\end{array}$ & $\begin{array}{l}\text { C8 column }(50 \times 2 \mathrm{~mm} ; 3 \mu \mathrm{m}) \\
\text { gradient starting with } 50 \% \text { methanol } \\
(0.1 \% \text { formic acid }), 50 \% \text { water } \\
(0.1 \% \text { formic acid })\end{array}$ & $\begin{array}{l}25(\mathrm{OH}) \mathrm{D}_{3} 383 / 211 \text { (quant), } \\
383 / 229 \text { (qual); } 25(\mathrm{OH}) \mathrm{D}_{2} \\
395 / 119 \text { (quant), 395/211 } \\
\text { (qual); } 25(\mathrm{OH}) \mathrm{D}_{3}-d_{6} 389 / 211\end{array}$ \\
\hline 242 & $25(\mathrm{OH}) \mathrm{D}_{3}-d_{6}$ & $\begin{array}{l}\text { Water with } 0.1 \% \text { formic acid ( } 500 \\
\mu \mathrm{L}) \text { and the IS }(400 \mu \mathrm{L}) \text { were } \\
\text { added to the sample }(400 \mu \mathrm{L}) \text {, } \\
\text { followed by centrifugation and } \\
\text { dilution of supernatant with water }\end{array}$ & $\begin{array}{l}\text { PFP column }(150 \times 2 \mathrm{~mm} ; 3 \mu \mathrm{m}) \text {; } \\
\text { isocratic elution with } 18 \% \text { water/ } \\
82 \% \text { methanol } / 0.1 \% \text { formic acid; } \\
\text { flow } 0.35 \mathrm{~mL} / \mathrm{min}\end{array}$ & 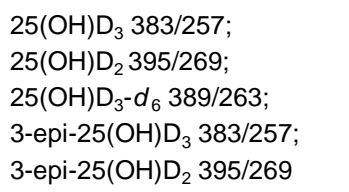 \\
\hline 244 & $25(\mathrm{OH}) \mathrm{D}_{3}-d_{6}$ & $\begin{array}{l}\text { Protein precipitation followed by } \\
\text { filtration }\end{array}$ & $\begin{array}{l}\text { CN column; mobile phase } \\
\text { consisting of distilled water (formic } \\
\text { acid) and methanol }\end{array}$ & $\begin{array}{l}25(\mathrm{OH}) \mathrm{D}_{2} 395 / 269 \\
25(\mathrm{OH}) \mathrm{D}_{3} 383 / 211\end{array}$ \\
\hline 248 & $\begin{array}{c}25(\mathrm{OH}) \mathrm{D}_{2}-d_{3} \text { and } \\
25(\mathrm{OH}) \mathrm{D}_{3}-d_{3}\end{array}$ & $\begin{array}{l}\text { Serum is precipitated with } \\
\text { methanol/ZnSO } \\
\text { and then with acetonitrile, } \\
\text { centrifuged, and injected }\end{array}$ & $\begin{array}{l}\text { Reversed-phase column }(75 \times 2.1 \\
\mathrm{mm} ; 2.5 \mu \mathrm{m}) \text {; gradient with water } \\
\text { and methanol; flow } 0.55 \mathrm{~mL} / \mathrm{min}\end{array}$ & $\begin{array}{l}25(\mathrm{OH}) \mathrm{D}_{3} 383 / 257,383 / 365 ; \\
25(\mathrm{OH}) \mathrm{D}_{2} 395 / 269,395 / 377 ; \\
25(\mathrm{OH}) \mathrm{D}_{3}-d_{3} 386 / 257 \\
386 / 368 ; \\
25(\mathrm{OH}) \mathrm{D}_{2}-\mathrm{d}_{3} 398 / 380 \\
398 / 272\end{array}$ \\
\hline 249 & $\begin{array}{c}25(\mathrm{OH}) \mathrm{D}_{2}-d_{3} \\
25(\mathrm{OH}) \mathrm{D}_{3}-d_{6} \\
\text { 3-epi-25(OH) } \mathrm{D}_{3}-d_{3}\end{array}$ & $\begin{array}{l}\text { Serum was deproteinated with } \\
\mathrm{NaOH} \text { and } 90 \% \text { acetonitrile/ } 10 \% \\
\text { methanol followed by SPE }\end{array}$ & $\begin{array}{l}\text { PFP column ( } 100 \times 2.1 \mathrm{~mm} ; 1.8 \\
\mu \mathrm{m}) ; \text { gradient separation with water } \\
(2 \mathrm{mmol} / \mathrm{L} \text { ammonium acetate) and } \\
\text { methanol; flow } 0.35 \mathrm{~mL} / \mathrm{min}\end{array}$ & $\begin{array}{l}25(\mathrm{OH}) \mathrm{D}_{3} 401 / 159 \\
25(\mathrm{OH}) \mathrm{D}_{2} 413 / 159\end{array}$ \\
\hline 250 & $\mathrm{n} / \mathrm{r}$ & Protein crash followed by SPE & $\begin{array}{l}\text { Phenyl column }(50 \times 2.1 \mathrm{~mm}) \\
\text { gradient with } 15 \% \text { water and } 85 \% \\
\text { methanol; flow } 0.45 \mathrm{~mL} / \mathrm{min}\end{array}$ & MRM \\
\hline 253 & $\begin{array}{c}25(\mathrm{OH}) \mathrm{D}_{2}-d_{3} \text { and } \\
25(\mathrm{OH}) \mathrm{D}_{3}-d_{3}\end{array}$ & $\begin{array}{l}\text { The sample was extracted, } \\
\text { centrifuged, and derivatized }\end{array}$ & $\begin{array}{l}\text { C18 column }(150 \times 2.1 \mathrm{~mm}) ; \\
\text { isocratic separation with } 22.5 \% \\
\text { water/ } 77.5 \% \text { methanol; flow } 0.2 \\
\mathrm{~mL} / \mathrm{min}\end{array}$ & $\begin{array}{l}25(\mathrm{OH}) \mathrm{D}_{2} 588 \\
25(\mathrm{OH}) \mathrm{D}_{3} 576\end{array}$ \\
\hline $254 a$ & $25(\mathrm{OH}) \mathrm{D}_{3}-d_{6}$ & $\begin{array}{l}\text { IS was added to each sample } \\
(200 \mu \mathrm{L}) \text { and mixed; acetontrile } \\
\text { was added, followed by mixing, } \\
\text { centrifugation, and injection }\end{array}$ & $\begin{array}{l}\text { C8 column }(50 \times 2.0 \mathrm{~mm} ; 3 \mu \mathrm{m}) \\
\text { elution with water and acetonitrile, } \\
\text { each containing } 0.1 \% \text { formic acid }\end{array}$ & $\begin{array}{l}25(\mathrm{OH}) \mathrm{D}_{3} 383 / 229,383 / 211 ; \\
25(\mathrm{OH}) \mathrm{D}_{2} 395 / 269,395 / 119 ; \\
25(\mathrm{OH}) \mathrm{D}_{3}-d_{6} 389 / 211\end{array}$ \\
\hline 255 & $\begin{array}{c}\text { deuterium labeled } \\
\text { compound }\end{array}$ & $\begin{array}{l}\text { Samples were extracted and } \\
\text { derivatized with 4-phenyl-I ,2,4- } \\
\text { triazoline-3,5-dione }\end{array}$ & $\begin{array}{l}\text { Reversed-phase column }(50 \times 2.1 \\
\mathrm{mm}) \text {; gradient with methanol; flow } \\
0.5 \mathrm{~mL} / \mathrm{min}\end{array}$ & $\begin{array}{l}25(\mathrm{OH}) \mathrm{D}_{3} 607 / 298 \\
25(\mathrm{OH}) \mathrm{D}_{2} 619 / 298\end{array}$ \\
\hline
\end{tabular}

$\mathrm{MRM}=$ multiple reaction monitoring; PFP = pentafluorophenyl; SPE = solid phase extraction; $\mathrm{n} / \mathrm{r}=$ not reported; $\mathrm{CN}=\mathrm{cyano} ;$ quant/qual = quantitative/qualitative ions 
Appendix A-3. Summary of LC-UV methods used by participants.

\begin{tabular}{|c|c|c|c|c|}
\hline $\begin{array}{l}\text { Laboratory } \\
\text { Number }\end{array}$ & $\begin{array}{c}\text { Internal } \\
\text { Standard (IS) }\end{array}$ & Sample Preparation & Chromatographic Conditions & Wavelength \\
\hline 110 & $\mathrm{n} / \mathrm{a}$ & $\begin{array}{l}\text { Samples }(500 \mu \mathrm{L}) \text { were mixed with } \\
\text { ethanol }(500 \mu \mathrm{L}) \text {, extracted twice } \\
\text { with hexane/methylene chloride } \\
(5: 1), \text { evaporated and } \\
\text { reconstituted }\end{array}$ & $\begin{array}{l}\text { C18 column }(2.1 \times 100 \mathrm{~mm} ; 1.8 \\
\mu \mathrm{m}) \text {; gradient with } \\
\text { acetonitrile/methanol }(85: 15) \text { and } \\
\text { isopropanol }(100 \%)\end{array}$ & $267 \mathrm{~nm}$ \\
\hline 139 & Proprietary & $\begin{array}{l}\text { The sample was extracted, } \\
\text { centrifuged and injected }\end{array}$ & $\begin{array}{l}\text { Reversed-phase column heated to } \\
40^{\circ} \mathrm{C} \text {, isocratic separation with } \\
\text { proprietary mobile phase; flow } 1 \\
\mathrm{~mL} / \mathrm{min}\end{array}$ & $264 \mathrm{~nm}$ \\
\hline 231 & 1alpha $(\mathrm{OH}) \mathrm{D}_{3}$ & $\begin{array}{l}\text { Samples were extracted with } \\
\text { hexane/dichloromethane, } \\
\text { evaporated and reconstituted with } \\
\text { mobile phase (phosphate } \\
\text { buffer/acetonitrile) }\end{array}$ & $\begin{array}{l}\text { Reversed-phase column }(250 \times 4.5 \\
\mathrm{mm} ; 5 \mu \mathrm{m}) \text {, isocratic separation with } \\
14 \% \text { phosphate buffer, } 86 \% \\
\text { acetonitrile; flow } 1.2 \mathrm{~mL} / \mathrm{min}\end{array}$ & $265 \mathrm{~nm}$ \\
\hline
\end{tabular}

$\mathrm{n} / \mathrm{a}=$ not applicable 
Appendix B-1. Raw participant data and NIST results for $25(\mathrm{OH}) \mathrm{D}_{2}, 25(\mathrm{OH}) \mathrm{D}_{3}$, 3-epi-25(OH)D $\mathrm{D}_{3}$, and $25(\mathrm{OH}) \mathrm{D}_{\text {Total }}$ in VitDQAP-II (Vial A), SRM 972a L4 (Vial B), and SRM 968d L1 (Control). 


\begin{tabular}{|c|c|c|c|c|c|c|c|c|c|c|c|c|c|}
\hline & & \multicolumn{3}{|c|}{$25(\mathrm{OH}) \mathrm{D}_{2}(\mathrm{ng} / \mathrm{mL})$} & \multicolumn{3}{|c|}{$25(\mathrm{OH}) \mathrm{D}_{3}(\mathrm{ng} / \mathrm{mL})$} & \multicolumn{3}{|c|}{$25(\mathrm{OH}) \mathrm{D}_{\text {Total }}(\mathrm{ng} / \mathrm{mL})$} & \multicolumn{3}{|c|}{ epi-25(OH)D $D_{3}(\mathrm{ng} / \mathrm{mL})$} \\
\hline & & VitDQAP-\|I & SRM 972a L4 & SRM 968d L1 & VitDQAP-II & SRM 972a L4 & SRM 968d L1 & VitDQAP-II & SRM 972a L4 & SRM 968d L1 & VitDQAP-II & SRM 972a L4 & SRM 968d L1 \\
\hline Lab & Method & Vial A & Vial B & \begin{tabular}{|c|} 
Control \\
\end{tabular} & Vial A & Vial B & \begin{tabular}{|c|} 
Control \\
\end{tabular} & Vial A & Vial B & \begin{tabular}{|c|} 
Control \\
\end{tabular} & Vial A & \begin{tabular}{|l|} 
Vial B \\
\end{tabular} & \begin{tabular}{|l|} 
Control \\
\end{tabular} \\
\hline 017 & CLIA & $n / a$ & $n / a$ & $\mathrm{n} / \mathrm{a}$ & $n / a$ & $\mathrm{n} / \mathrm{a}$ & $n / a$ & 36.8 & 27.0 & 13.0 & $n / r$ & $n / r$ & $n / r$ \\
\hline 030 & RIA & $\mathrm{n} / \mathrm{a}$ & $\mathrm{n} / \mathrm{a}$ & $\mathrm{n} / \mathrm{a}$ & $n / a$ & $\mathrm{n} / \mathrm{a}$ & $\mathrm{n} / \mathrm{a}$ & 33.6 & 26.3 & 12.8 & $n / r$ & $n / r$ & $n / r$ \\
\hline 056 & LC-MS/MS & 0.6 & 0.7 & 0.2 & 35.8 & 26.8 & 12.1 & 36.4 & 27.5 & 12.3 & 3.5 & 24.3 & 1.8 \\
\hline 060 & LC-MS/MS & $<0.5$ & $<0.5$ & $<0.5$ & 39.4 & 30.9 & 12.8 & 39.4 & 30.9 & 12.8 & 3.3 & 28.7 & 0.7 \\
\hline $086 a$ & CLIA & $\mathrm{n} / \mathrm{a}$ & $\mathrm{n} / \mathrm{a}$ & $\mathrm{n} / \mathrm{a}$ & $\mathrm{n} / \mathrm{a}$ & $\mathrm{n} / \mathrm{a}$ & $\mathrm{n} / \mathrm{a}$ & 40.7 & 30.7 & 14.0 & $n / r$ & $n / r$ & $n / r$ \\
\hline 110 & LC-UV & $<2$ & $<2$ & $<2$ & 30.1 & 44.7 & 13.2 & 30.1 & 44.7 & 13.2 & $n / r$ & $n / r$ & $n / r$ \\
\hline 116 & LC-MS/MS & $<3.3$ & $<3.3$ & $<3.3$ & 36.7 & 24.4 & 16.5 & 36.7 & 24.4 & 16.5 & 5.8 & 27.3 & $<4.0$ \\
\hline 119 & LC-MS/MS & $n / r$ & $n / r$ & $n / r$ & 56.0 & 87.0 & 20.0 & 56.0 & 87.0 & 20.0 & $n / r$ & $n / r$ & $n / r$ \\
\hline 128 & LC-MS/MS & $\mathrm{n} / \mathrm{a}$ & $\mathrm{n} / \mathrm{a}$ & $\mathrm{n} / \mathrm{a}$ & 24.8 & 33.5 & 12.3 & 24.8 & 33.5 & 12.3 & $n / r$ & $n / r$ & $n / r$ \\
\hline 139 & LC-UV & $n / r$ & $n / r$ & $n / r$ & $n / r$ & $n / r$ & $n / r$ & 44.2 & 64.4 & 14.7 & $n / r$ & $n / r$ & $n / r$ \\
\hline $183 b$ & CLIA & $\mathrm{n} / \mathrm{a}$ & $\mathrm{n} / \mathrm{a}$ & $n / a$ & $n / a$ & $\mathrm{n} / \mathrm{a}$ & $n / a$ & 37.0 & 29.2 & 13.5 & $n / r$ & $n / r$ & $n / r$ \\
\hline 187 & LC-MS/MS & $<1.5$ & $<1.5$ & $<1.5$ & 39.6 & 59.7 & 12.5 & 39.6 & 59.7 & 12.5 & $n / r$ & $n / r$ & $n / r$ \\
\hline 188 & CLIA & $n / a$ & $\mathrm{n} / \mathrm{a}$ & $\mathrm{n} / \mathrm{a}$ & $n / a$ & $\mathrm{n} / \mathrm{a}$ & $\mathrm{n} / \mathrm{a}$ & 47.0 & 35.2 & 13.6 & $n / r$ & $n / r$ & $n / r$ \\
\hline 194 & LC-MS/MS & $<7$ & $<7$ & $<7$ & 43.4 & 64.5 & 12.5 & 43.4 & 64.5 & 12.5 & $n / r$ & $n / r$ & $n / r$ \\
\hline 196 & CLIA & $n / a$ & $\mathrm{n} / \mathrm{a}$ & $n / a$ & $\mathrm{n} / \mathrm{a}$ & $\mathrm{n} / \mathrm{a}$ & $\mathrm{n} / \mathrm{a}$ & 40.9 & 29.6 & 14.6 & $n / r$ & $n / r$ & $n / r$ \\
\hline 197 & LC-MS/MS & $<0.5$ & $<0.5$ & $<0.5$ & 33.9 & 46.7 & 12.8 & 33.9 & 46.7 & 12.8 & $n / r$ & $n / r$ & $\mathrm{n} / \mathrm{r}$ \\
\hline $198 a$ & LC-MS/MS & $<5.0$ & $<5.0$ & $<5.0$ & 49.7 & 56.6 & 11.4 & 49.7 & 56.6 & 11.4 & $n / r$ & $n / r$ & $n / r$ \\
\hline $198 \mathrm{c}$ & CLIA & $\mathrm{n} / \mathrm{a}$ & $\mathrm{n} / \mathrm{a}$ & $\mathrm{n} / \mathrm{a}$ & $\mathrm{n} / \mathrm{a}$ & $\mathrm{n} / \mathrm{a}$ & $\mathrm{n} / \mathrm{a}$ & 40.8 & 26.6 & 15.4 & $n / r$ & $\mathrm{n} / \mathrm{r}$ & $\mathrm{n} / \mathrm{r}$ \\
\hline 199 & LC-MS/MS & $<2$ & $<2$ & $<2$ & 41.5 & 71.0 & 12.7 & 41.5 & 71.0 & 12.7 & $n / r$ & $n / r$ & $n / r$ \\
\hline 200 & RIA & $n / a$ & $\mathrm{n} / \mathrm{a}$ & $n / a$ & $\mathrm{n} / \mathrm{a}$ & $\mathrm{n} / \mathrm{a}$ & $\mathrm{n} / \mathrm{a}$ & 30.8 & 22.9 & 12.8 & $n / r$ & $n / r$ & $n / r$ \\
\hline 209 & LC-MS/MS & $<1.0$ & $<1.0$ & $<1.0$ & 42.4 & 49.7 & 13.0 & 42.4 & 49.7 & 13.0 & $n / r$ & $n / r$ & $n / r$ \\
\hline $210 a$ & RIA & $n / a$ & $\mathrm{n} / \mathrm{a}$ & $\mathrm{n} / \mathrm{a}$ & $n / a$ & $n / a$ & $n / a$ & 38.5 & 34.5 & 8.5 & $n / r$ & $n / r$ & $n / r$ \\
\hline $210 b$ & CLIA & $\mathrm{n} / \mathrm{a}$ & $\mathrm{n} / \mathrm{a}$ & $n / a$ & $n / a$ & $n / a$ & $\mathrm{n} / \mathrm{a}$ & 40.8 & 39.8 & $<3.0$ & $n / r$ & $n / r$ & $n / r$ \\
\hline 211 & LC-MS/MS & 0.0 & 0.0 & 0.0 & 42.0 & 58.0 & 15.3 & 42.0 & 58.0 & 15.3 & $n / r$ & $n / r$ & $n / r$ \\
\hline $213 a$ & CLIA & $\mathrm{n} / \mathrm{a}$ & $\mathrm{n} / \mathrm{a}$ & $\mathrm{n} / \mathrm{a}$ & $\mathrm{n} / \mathrm{a}$ & $\mathrm{n} / \mathrm{a}$ & $\mathrm{n} / \mathrm{a}$ & 49.2 & 49.8 & 9.0 & $n / r$ & $\mathrm{n} / \mathrm{r}$ & $\mathrm{n} / \mathrm{r}$ \\
\hline $214 b$ & CLIA & $\mathrm{n} / \mathrm{a}$ & $\mathrm{n} / \mathrm{a}$ & $n / a$ & $n / a$ & $n / a$ & $n / a$ & 39.6 & 28.8 & 13.1 & $n / r$ & $n / r$ & $n / r$ \\
\hline $214 c$ & LC-MS/MS & $<1.0$ & $<1.0$ & $<1.0$ & 36.1 & 53.7 & 12.1 & 36.1 & 53.7 & 12.1 & $n / r$ & $\mathrm{n} / \mathrm{r}$ & $\mathrm{n} / \mathrm{r}$ \\
\hline 215 & LC-MS/MS & 0.0 & 0.4 & 0.0 & 40.4 & 56.8 & 13.9 & 40.4 & 57.2 & 13.9 & $n / r$ & $n / r$ & $n / r$ \\
\hline 216 & LC-MS/MS & 0.4 & 0.4 & 0.1 & 37.8 & 28.9 & 12.5 & 38.2 & 29.3 & 12.6 & 3.1 & 27.0 & 0.6 \\
\hline 217 & LC-MS/MS & $<2$ & $<2$ & $<2$ & 37.2 & 54.0 & 12.8 & 37.2 & 54.0 & 12.8 & $n / r$ & $n / r$ & $n / r$ \\
\hline $218 a$ & CLIA & $\mathrm{n} / \mathrm{a}$ & $\mathrm{n} / \mathrm{a}$ & $\mathrm{n} / \mathrm{a}$ & $n / a$ & $\mathrm{n} / \mathrm{a}$ & $n / a$ & 37.5 & 28.6 & 12.8 & $n / r$ & $n / r$ & $n / r$ \\
\hline $218 b$ & LC-MS/MS & 0.0 & 0.0 & 0.0 & 42.3 & 42.7 & 13.1 & 42.3 & 42.7 & 13.1 & $n / r$ & $n / r$ & $n / r$ \\
\hline 220 & LC-MS/MS & $<5.0$ & $<5.0$ & $<5.0$ & 39.0 & 59.0 & 13.0 & 39.0 & 59.0 & 13.0 & $n / r$ & $n / r$ & $n / r$ \\
\hline $221 a$ & LC-MS/MS & 0.0 & 0.0 & 0.0 & 35.5 & 25.1 & 16.9 & 35.5 & 25.1 & 16.9 & $n / r$ & $\mathrm{n} / \mathrm{r}$ & $\mathrm{n} / \mathrm{r}$ \\
\hline 222 & CLIA & $\mathrm{n} / \mathrm{a}$ & $\mathrm{n} / \mathrm{a}$ & $n / a$ & $\mathrm{n} / \mathrm{a}$ & $\mathrm{n} / \mathrm{a}$ & $\mathrm{n} / \mathrm{a}$ & 51.6 & 34.8 & 12.4 & $n / r$ & $n / r$ & $n / r$ \\
\hline 225 & LC-MS/MS & $<5.0$ & $<5.0$ & $<5.0$ & 44.6 & 65.9 & 11.2 & 44.6 & 65.9 & 11.2 & $n / r$ & $n / r$ & $n / r$ \\
\hline $228 a$ & LC-MS/MS & $\mathrm{n} / \mathrm{d}$ & $\mathrm{n} / \mathrm{d}$ & $\mathrm{n} / \mathrm{d}$ & 34.6 & 51.6 & 12.4 & 34.6 & 51.6 & 12.4 & $n / r$ & $n / r$ & $n / r$ \\
\hline 231 & LC-UV & $n / d$ & $n / d$ & $n / d$ & 41.3 & 56.4 & $n / r$ & 41.3 & 56.4 & $n / r$ & $n / r$ & $n / r$ & $n / r$ \\
\hline 241 & LC-MS/MS & $<0.5$ & $<0.5$ & $n / d$ & 43.3 & 68.0 & 14.9 & 43.3 & 68.0 & 14.9 & $n / r$ & $n / r$ & $n / r$ \\
\hline 242 & LC-MS/MS & $\mathrm{n} / \mathrm{d}$ & $\mathrm{n} / \mathrm{d}$ & $n / d$ & 35.1 & 30.5 & 11.9 & 35.1 & 30.5 & 11.9 & 2.6 & 20.7 & 0.6 \\
\hline 244 & LC-MS/MS & $<5$ & $<5$ & $<5$ & 36.5 & 43.1 & 12.5 & 36.5 & 43.1 & 12.5 & $n / r$ & $n / r$ & $n / r$ \\
\hline $247 a$ & CLIA & n/a & $\mathrm{n} / \mathrm{a}$ & $n / a$ & $\mathrm{n} / \mathrm{a}$ & $\mathrm{n} / \mathrm{a}$ & $\mathrm{n} / \mathrm{a}$ & 50.0 & 34.1 & 13.1 & $n / r$ & $n / r$ & $n / r$ \\
\hline 248 & LC-MS/MS & $<3.0$ & $<3.0$ & $<3.0$ & 42.7 & 55.4 & 14.1 & 43.0 & 55.0 & 14.0 & $n / r$ & $n / r$ & $\mathrm{n} / \mathrm{r}$ \\
\hline 249 & LC-MS/MS & $<0.8$ & $<0.8$ & $<0.8$ & 36.4 & 29.1 & 12.4 & 36.4 & 29.1 & 12.4 & 3.2 & 28.5 & 0.4 \\
\hline 250 & LC-MS/MS & $<2.5$ & $<2.5$ & $<2.5$ & 44.3 & 67.7 & 13.9 & 44.3 & 67.7 & 13.9 & $n / r$ & $n / r$ & $n / r$ \\
\hline 253 & LC-MS/MS & 0.5 & 0.5 & 0.2 & 41.2 & 32.5 & 13.9 & 41.7 & 33.0 & 14.1 & 3.4 & 25.8 & 0.7 \\
\hline $254 a$ & LC-MS/MS & 0.1 & 0.1 & 0.0 & 40.3 & 59.4 & 12.9 & 40.5 & 59.5 & 12.9 & $n / r$ & $n / r$ & $n / r$ \\
\hline $254 b$ & CLIA & $\mathrm{n} / \mathrm{a}$ & $\mathrm{n} / \mathrm{a}$ & $\mathrm{n} / \mathrm{a}$ & $\mathrm{n} / \mathrm{a}$ & $\mathrm{n} / \mathrm{a}$ & $\mathrm{n} / \mathrm{a}$ & 37.5 & 29.6 & 12.5 & $n / r$ & $n / r$ & $n / r$ \\
\hline 255 & LC-MS/MS & 0.6 & 0.5 & 0.3 & 49.5 & 59.9 & 16.1 & 50.1 & 60.4 & 16.4 & $n / r$ & $n / r$ & $n / r$ \\
\hline
\end{tabular}

$\mathrm{n} / \mathrm{a}=$ not applicable (for immunoassay methods); $\mathrm{n} / \mathrm{r}=$ not reported; $\mathrm{n} / \mathrm{d}=$ not detected; $<\mathrm{X}=$ less than a reported quantitation limit of $\mathrm{X}$

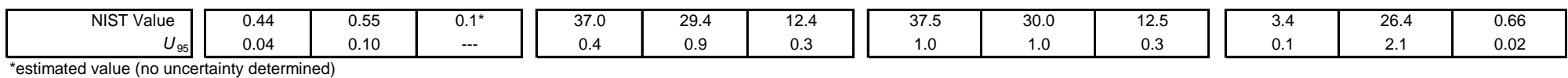

